\title{
WestVirginiaUniversity
}

THE RESEARCH REPOSITORY @ WVU

Graduate Theses, Dissertations, and Problem Reports

2014

\section{Three essays on the political economy of forensic science}

William P. McAndrew

West Virginia University

Follow this and additional works at: https://researchrepository.wvu.edu/etd

\section{Recommended Citation}

McAndrew, William P., "Three essays on the political economy of forensic science" (2014). Graduate Theses, Dissertations, and Problem Reports. 420.

https://researchrepository.wvu.edu/etd/420

This Dissertation is protected by copyright and/or related rights. It has been brought to you by the The Research Repository @ WVU with permission from the rights-holder(s). You are free to use this Dissertation in any way that is permitted by the copyright and related rights legislation that applies to your use. For other uses you must obtain permission from the rights-holder(s) directly, unless additional rights are indicated by a Creative Commons license in the record and/ or on the work itself. This Dissertation has been accepted for inclusion in WVU Graduate Theses, Dissertations, and Problem Reports collection by an authorized administrator of The Research Repository @ WVU.

For more information, please contact researchrepository@mail.wvu.edu. 


\title{
THREE ESSAYS ON THE POLITICAL ECONOMY OF FORENSIC SCIENCE
}

\author{
William P. McAndrew \\ Dissertation submitted to the \\ College of Business and Economics \\ at West Virginia University \\ in partial fulfillment of the requirements \\ for the degree of \\ Doctor of Philosophy \\ in \\ Economics
}
Paul J. Speaker, Ph.D., Chair
Roger D. Congleton, Ph.D.
Joshua C. Hall, Ph.D.
Amanda Ross, Ph.D.
Russell S. Sobel, Ph.D.

Department of Economics
Morgantown, West Virginia
2014

Keywords: Leviathan; Fiscal Federalism; Public Goods; Forensic Science

Copyright 2014 William P. McAndrew 


\section{ABSTRACT \\ Three Essays on the Political Economy of Forensic Science}

\section{William P. McAndrew}

This dissertation is a collection of three essays which explores how public choice and public finance issues affect the provision and production of local public goods. This dissertation looks specifically at the provision of forensic science services. Chapter 2 explores the methodology in measuring how public or private a good is, and finds that ignoring the "zoo effect" can cause upward bias in the measurement of how private a good is. Chapter 3 estimates the cost differences between nationally and locally operated forensic science laboratories, and using an average total cost function, determines that nationally operated laboratories are not more or less efficient than sub-national laboratories. Finally, chapter 4 explores the Leviathan model, and finds that governments can, and in the case of the Deficit Reduction Act of 1984 do, operate in ways that reduce tax revenues. 


\section{ACKNOWLEDGEMENTS}

First and foremost I thank my parents, Dennis and Deborah McAndrew, for their constant encouragement and support of my education. My education was always a priority of theirs, and without their financial support through private schools and college, and the hours of time they spent with me as a child going over my lessons, I doubt very much I would have been as successful as I have been.

I also owe an enormous debt of gratitude to my wife Angela McAndrew, who has encouraged me since high school to better myself, and eventually followed me all the way to West Virginia to support me and my chosen goals. I doubt this would have been possible without her. My inlaws, Edward and Christine Dahlkemper, have also been a constant source of love and support.

I will always be grateful to my dissertation adviser and mentor, Dr. Paul Speaker. Writing and coauthoring papers with Paul has been such a rewarding experience for me, which I hope continues for years to come.

I would also like to thank the other members of my dissertation committee, Dr. Roger Congleton, Dr. Joshua Hall, Dr. Amanda Ross, and Dr. Russell Sobel. Thank you for all of your helpful comments, suggestions, corrections, and advice. Additional thanks to Dr. James Kurre, Dr. Todd Nesbit, and Dr. Max Houck for their interest and support of my career success.

Finally, thank you to everyone in the economics department, past and present, at West Virginia University for all of the help, advice, and encouragement you have given me these past five years.

\section{Publication Information}

Some paragraphs and wording of the third chapter in this dissertation were previously published in the January 2012 issue of Forensic Science Policy \& Management. This wording is reprinted with updated and adapted material for this dissertation with the permission of the publisher (Taylor \& Francis Ltd, http://www.tandfonline.com). 


\section{TABLE OF CONTENTS}

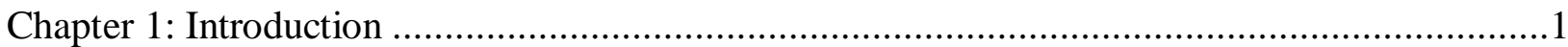

Chapter 2: How 'Public' are Local Public Goods? Empirical Evidence Using Data from the

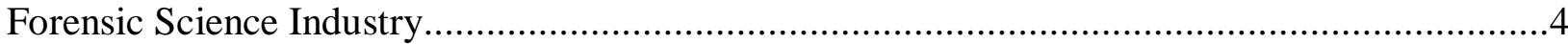

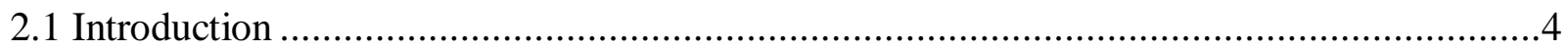

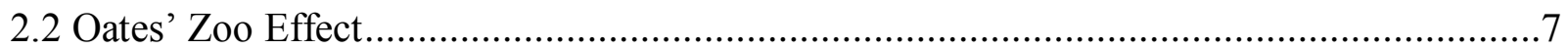

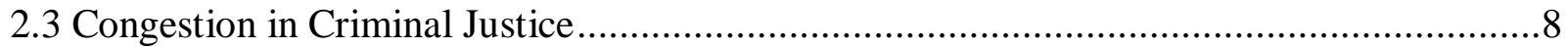

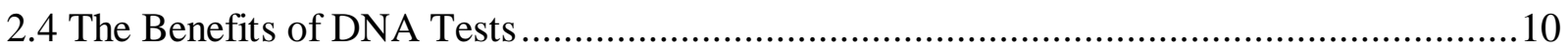

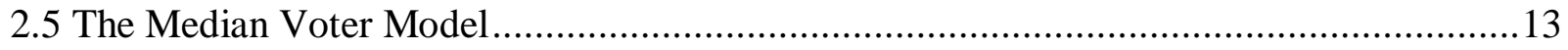

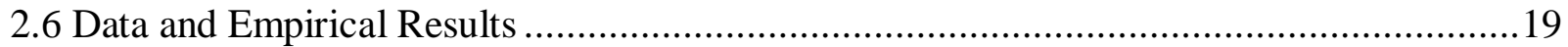

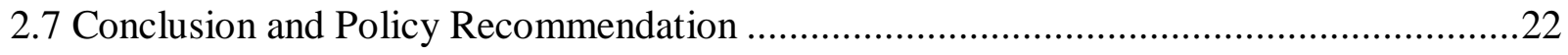

Chapter 3: The Limits of Constraining Leviathan ......................................................................

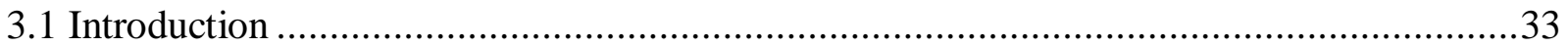

3.2 Fiscal Federalism and the Provision of Local Public Goods ..............................................37

3.2.1 What Level of Government Ought to Provide a Given Quantity of Output? .................37

3.2.2 What is the Optimal Quantity of Output to be Provided? ...........................................41

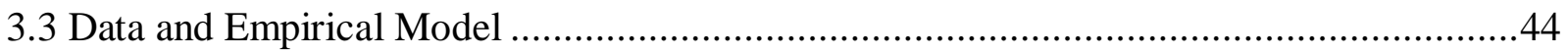

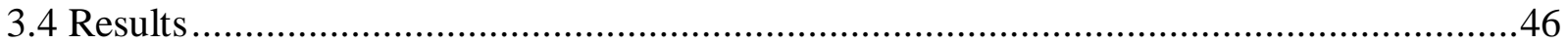

3.5 Conclusion and Policy Recommendation ..................................................................... 47

Chapter 4: When Leviathans Fail to Maximize Revenue: A Theoretical Analysis of the Social

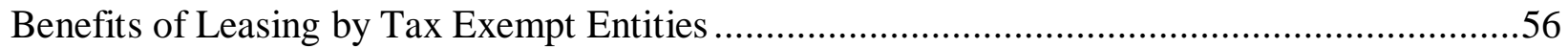

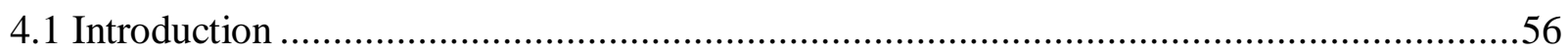

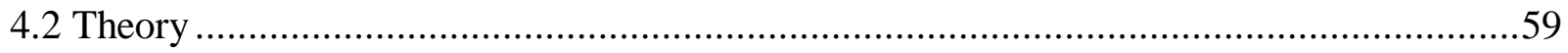

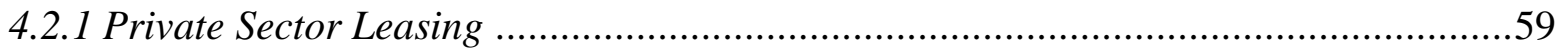

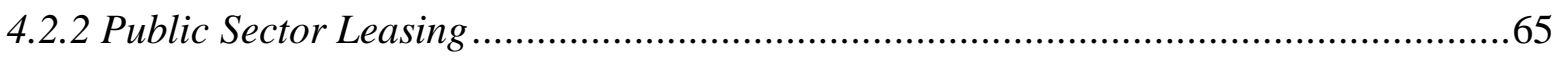

4.3 Conclusion and Policy Recommendation ......................................................................68

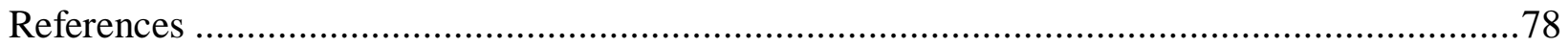




\section{LIST OF TABLES}

Table 2.1: Descriptive Statistics .27

Table 2.2: 2010 OLS Cross Section Estimate of Total DNA Expenditure .............................28

Table 2.3: 2010 Poisson Cross Section Estimate of Unit Level DNA Report Output................29

Table 2.4: 2010 Poisson Cross Section Estimate of Unit Level DNA Test Output .....................30

Table 2.5: 2010 Poisson Cross Section Estimate of Unit Level DNA Case Output....................31

Table 2.6: 2010 Poisson Cross Section Estimate of Unit Level DNA Sample Output................32

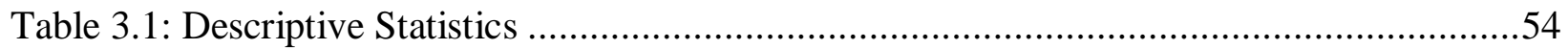

Table 3.2: OLS Estimate of the Long Run Average Cost of a Criminal DNA Case ..................55

Table 4.1: Cash Flows Derived from Purchasing a Capital Asset ......................................... 70

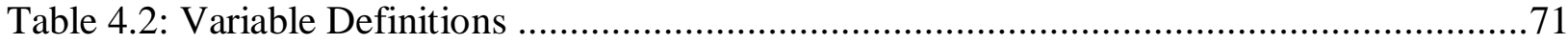

Table 4.3: Cash Flows from the Purchase of a Capital Asset by a Firm...................................72

Table 4.4: Cash Flows a Lessor Receives by Leasing to a Firm .........................................73

Table 4.5: Cash Flows a Firm Receives from Leasing …........................................... 74

Table 4.6: Cash Flows from the Purchase of a Capital Asset by a Public Sector Agency...........75

Table 4.7: Cash Flows a Public Sector Agency Receives from Leasing ..................................76

Table 4.8: Cash Flows a Lessor Receives by Leasing to a Public Sector Agency ......................77 


\section{LIST OF FIGURES}

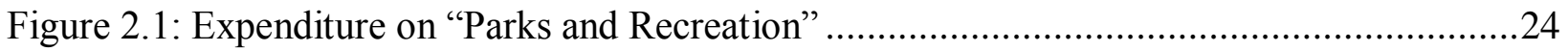

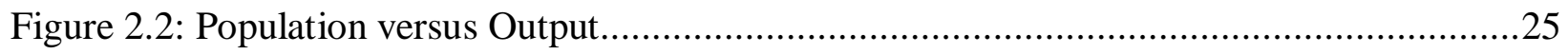

Figure 2.3: Deriving the Social Marginal Benefit Curve …...........................................26

Figure 3.1: Centralized Versus Decentralized Output Decisions for Forensic Science Services ..50

Figure 3.2: The Optimal Forensic Science Service Area Size ...........................................51

Figure 3.3: Short Run and Long Run Average Total Cost of Forensic Science Services............52

Figure 3.4: Long Run Average Cost of Criminal DNA Cases ..............................................53 


\section{Chapter 1}

\section{Introduction}

Political economists and other scholars have studied government outputs and the framework in which they are provided for centuries. Given the multiplicity of public outputs and public interests within political jurisdictions at various levels of government, understanding how to provide these goods efficiency and equitably is a complex issue of concern. In some circumstances, local governments ought to provide a certain public good, whereas in other circumstances a tri-county, state, regional, or some other system may be more efficient. Efficiency as a goal however is made more difficult by the territorial boundaries of government units which often halt cooperation across borders, a situation which private markets do not have to contend with. Special purpose governments such as school districts have thus been developed in an effort to overcome the constraints of political borders in order to operate more efficiently. The geographic or population size a special purpose government ought to serve, and the level of output to be produced, are provision and production issues respectively and will vary with each public good. Thus, understanding the demand decisions of a community and how to effectively supply those demands are both empirical questions which differ from good to good.

The growth in detailed quality datasets in recent years now allows for an improved exploration into this empirical issue, which was less possible in past decades due to data limitations. With detailed data on specific industries, more targeted and accurate public policy recommendations can be made for the provision and production of local public goods. This dissertation contributes to the public finance and public choice literature by using a new National Institute of Justice dataset covering the forensic science industry, which allows for this detailed exploration of the provision and production of publicly provided goods. 
Chapter 2 explores the methodology behind measuring how public or private a good is in the Samuelsonian sense. Over the past several decades, there has been a stream of empirical research that estimates demand functions for a wide array of local public outputs. A common functional form of the demand equations within this literature allows for a congestion parameter to be estimated. One common finding has been that most local public outputs have a high degree of congestion, which implies local public outputs are private, and thus demand decisions ought to occur at an individual rather than community level. This result is surprising since the demand decisions of local public goods are most often made by local governments, not individuals. Chapter 2 shows that measurement error can cause estimated congestion parameters to exhibit upward bias. Specifically, this essay is the first to empirically test whether Wallace Oates' "zoo effect" exists, and finds support for its existence which causes an overestimation of congestion when not accounted for.

Chapter 3 investigates the Leviathan model as a general explanation for government size. Public choice economists commonly point to jurisdictional fragmentation, or sub-national government competition, as a way to constrain the Leviathan of government sector bureaucracy. The empirical literature which describes both the determinants of public sector size and government size's effect on the welfare of a population is mixed. Chapter 3's purpose is to shed light on why the literature is mixed by exploring differences in the long run and short run cost efficiency of a particular good at a national and sub-national level. Evidence in this chapter suggests that provision of output by national systems which have a greater ability to tax compared to sub-national governments does not necessarily lead to a greater level of spending overall, casting doubt on the Leviathan model as a general explanation for the size of government. 
Chapter 4 continues the investigation into the Leviathan model as a general explanation for government size by exploring regulations on leasing by tax-exempt entities. Several reasons why governments may not behave as Leviathans have been previously proposed. Chapter 4 contributes to the literature by proposing a new reason, being that national governments frequently have stated goals counter to the aim of revenue maximization in the policies they form. Using the Deficit Reduction Act (DEFRA) of 1984 as an example, a theoretical framework is developed showing that national governments can indeed form policies which reduce rather than maximize revenue. The reduction in federal revenue after DEFRA was enacted however comes at a cost, being a lower degree of consumption of capital goods at the margin. 


\section{Chapter 2}

\section{How 'Public' are Local Public Goods? Empirical Evidence Using Data from the Forensic Science Industry}

\subsection{Introduction}

Two influential papers published by Borcherding and Deacon (1972) and Bergstrom and Goodman (1973) four decades ago have inspired a stream of empirical research which estimates demand functions for a wide array of local public outputs, including Deno and Mehay (1987), Holcombe and Sobel (1995), King (2007), and Mathers (2009). The common functional form of the demand equations within this literature not only allows for an estimate of the population and price elasticity of demand for respective outputs, but also for a congestion parameter to be calculated. This congestion parameter represents how public or private a good is in the manner described by Samuelson (1954), and can allow for important policy recommendations to be made based upon estimates of the demand behavior of society towards a particular good. A common policy recommendation has been that if a good is a public good, governments ought to provide for its output.

More explicitly, the relationship between consumption and population follows the form $\mathrm{f}=\mathrm{F} / \mathrm{N}^{\gamma}$ where $\mathrm{F}$ is the total number of units of a given type of production provided to a community, $\mathrm{f}$ is the level of consumption of a representative individual in the community of this production, $\mathrm{N}$ is the population size, and $\gamma$ is the congestion parameter. $\mathrm{F}$ is a public good if $\mathrm{F}=\mathrm{f}$, which implies that a representative individual consumes the entire production provided to the community. A classic example of this is a missile defense shield, where every individual can consume the entire output, regardless of consumption by other individuals. This situation can only occur when the congestion parameter $\gamma=0$, assuming communities have a population 
greater than one. If a good is a private good, demand behavior will be different. Private goods exist when an increase in population leads to a proportional increase in output. For example, total food consumption of a population increases as population increases, ceteris paribus. This occurs due to crowding, or the rivalrous nature of many goods such as food. One unit of food simply cannot be consumed by multiple people. When crowding sets in, $\gamma$ can rise up to the point where $\gamma=1$, which implies that congestion is complete or that the good is a purely private good. For a purely private $\operatorname{good} \mathrm{f}=\mathrm{F} / \mathrm{N}$.

One common finding in the empirical literature has been that most local public outputs have a high degree of congestion with $\gamma$ congestion parameters often near or greater than unity (Oates 1988). Taken at face value, this implies local public goods are private or quasi-private goods, and thus demand decisions for these goods ought to occur at an individual rather than community level. This result is surprising since the demand decisions of local public goods are made by local governments on behalf of a community, and are not made by individuals. Deno and Mehay (1987), for example, find that the production of police protection, fire protection, and parks behave as private goods with $\gamma$ congestion parameters equal to or greater than unity. The demand for these services however comes from large sharing groups or communities, which makes this finding counterintuitive. In normal circumstances one could observe in reality, one would simply not see individuals determining the level of their police protection. Groups, through the voting process, determine this production.

Economic explanations for this contradictory result are possible. For example, bureaucratic power and thus the size of budgets may be positively correlated with population size (Borcherding et al. 1977). However in this current paper the focus is on estimation techniques which when done improperly can result in congestion parameters that exhibit upward bias. 
Specifically, this paper is believed to be the first to empirically test whether Oates' "zoo effect" exists (Oates 1988) ${ }^{1}$. Building on the findings from Schmandt and Stephens (1960), who estimate a demand function using the total number of distinct subfunctions of a municipal output rather than using expenditure data as laid out in Borcherding and Deacon (1972) and Bergstrom and Goodman (1973), Oates (1988) identifies a methodological weakness of the empirical estimation used to estimate demand functions of local public goods. Specifically, by failing to recognize that demand behavior and observed consumption bundles vary from large to small jurisdictions, commonly used expenditure data fails to capture the true effect of population changes on demand. Upward bias in the congestion parameter will then result from ignoring the fact that large jurisdictions tend to provide not only a greater level of output, but also a wider range of outputs, which leads to higher government expenditures and a higher cost of living for a population.

Using a new National Institute of Justice dataset on the criminal DNA analysis output of forensic science laboratories in the U.S. and internationally, the results of this paper suggest Oates' "zoo effect" does exist, which when unaccounted for will cause an upward bias on the estimated population elasticity coefficient and also the calculated congestion parameter. When the "zoo effect" is considered by using disaggregated count data rather than the more common but less appropriate aggregated expenditure data, the population elasticity coefficient and thus congestion parameter measures are estimated significantly lower. This result offers evidence for improvement in the estimation technique used to measure the congestion of local public goods, which can be implemented as the literature moves forward.

The remainder of the discussion to follow formalizes what has been suggested above. In section 2.2 Oates' "zoo effect" is explained in greater detail. In section 2.3 and 2.4 the nature of

\footnotetext{
${ }^{1}$ Section 2.2 explains the zoo effect in detail
} 
the benefits from criminal DNA analysis is discussed along with how the market failure of positive externalities affect the optimal consumption decision of a jurisdiction. In section 2.5 a median voter model is formally presented and an empirical model developed to estimates a demand function for criminal DNA analysis. Section 2.6 explains the results of the empirical model and section 2.7 offers concluding remarks.

\subsection{Oates' Zoo Effect}

Oates (1988) offers a hypothetical example to illustrate an effect termed the "zoo effect" by exploring spending on zoos. He considers a case where municipal zoos have a fixed annual expenditure of $\$ 1$ million to operate, and the willingness of individuals to pay for zoos is $\$ 1$ per year in every jurisdiction. In this case, jurisdictions with a population greater than 1 million would support a zoo, and those with less than 1 million would not. ${ }^{2}$ When a growing population reaches 1 million individuals, the first "unit" of zoo output would require a substantial expenditure. The expenditure of local public goods therefore cannot be a linear function of population given that expenditure contains certain jumps or discontinuities that come from larger jurisdictions providing a wider range and not just level of output. If an empirical economist were then to estimate a congestion parameter of an aggregated output called "parks and recreation" which includes the expenditures on all parks, walking paths, zoos, playgrounds, etc., the discontinuities that come with zoo output would be lost and would lead to an overestimation of the effect of population on the demand for "parks and recreation." This effect is illustrated in Figure 2.1..$^{3}$

\footnotetext{
${ }^{2}$ This example assumes that zoos come in a fixed size, which is simplistic. It is clear though that very small jurisdictions normally have an expenditure of zero on zoos. The purpose of this example is thus to illustrates the indivisibilities which come with many local public goods, and how consumption bundles vary with population.

${ }^{3}$ Discontinuity in output is an intuitive way to understand the zoo effect, however the zoo effect is the effect population size has on the range or bundle of outputs a jurisdiction produces. A regression discontinuity design is therefore not the purpose or focus of this paper. Rather, this paper uses disaggregated output data that accounts for the zoo effect and a changing consumption bundle.
} 
Implicit in the "zoo effect" is that larger jurisdictions have a higher cost of living as well, ceteris paribus, in part from the greater range of services being offered which require a larger expenditure to fund. The prices or taxes that fund local public outputs are higher as a result in larger jurisdictions compared to smaller jurisdictions. If expenditure data is used to estimate demand, price differences across jurisdictions will also be ignored and the effect of population on output and the congestion parameter will again be overestimated. Holcombe and Sobel (1995) recognize this and attempt to control for price differences across jurisdictions by controlling for salary. This current paper expands upon that method and is able to perfectly control for price differences through use of unit level output data rather than expenditure data.

\subsection{Congestion in Criminal Justice}

When a local public output contains a high degree of congestion, it is a public good which constitutes a market failure resulting from an under allocation of the good. The reason public goods lead to a market failure is that they cause positive externalities onto those in society who do not pay for the good but still receive some benefit from it, resulting in free riders and underproduction of the good. Consider one publicly provided good, criminal DNA analysis. In the case of criminal DNA analysis, which is the empirical focus of this paper, there are positive externalities if DNA testing leads to criminal convictions that increase the level of safety in society for everyone, since social safety is nonexcludable and nonrival in many cases.

However, these external benefits are not always relevant to the demand decision of the jurisdictions that forensic science laboratories serve. Holcombe (1996), and King (2007) point out that in some cases externalities from public goods are inframarginal and do not necessarily entail a market failure. With inframarginal externalities there may be total externality effects, but no marginal externality effects so output behavior is unaffected. As an example, consider the 
Bikini Atoll which is a series of islands in the Pacific Ocean, two of which were populated and needed to be evacuated for use as a nuclear bomb testing site during World War II. Although the initial bomb test caused a negative externality on the evacuated population, any subsequent bomb tests were inframarginal as any increase in the number of bomb tests beyond one could not continue to harm those evacuated beyond the initial bomb test.

The present study addresses this point and seeks to determine whether external benefits affect the criminal DNA analysis consumption decision by the populations served by forensic laboratories. The nuances of the forensic science industry pose challenges in answering this question since the consumer of criminal DNA analysis is not usually a well defined individual, but rather could be a police department, the prosecution, or more broadly the tax payers of a jurisdiction (McAndrew 2012a). The output of forensic laboratories is difficult to define as well (Houck et al. 2009) since DNA analysis also contributes to the output of safety and justice. However, individual laboratory output behavior, which is objectively measurable, can still give clues to whether a market failure exists. Specifically, if DNA analysis tends to rise as populations and thus crime also rise (suggesting rivalrous consumption behavior or crowding) as seen in Figure 2.2, then there would exist degrees of private incentives. In this case, output decisions would be optimally determined at a decentralized rather than centralized level, which would allow for the individual preferences of jurisdictions' populations to be met.

The degree to which criminal DNA analysis behaves as a private versus a public good will determine the appropriate institutional framework within which to provide this good. If jurisdictions have a private incentive to provide the optimal amount of criminal DNA analysis, a decentralized system with market mechanisms would be the appropriate framework. Alternatively, if jurisdictions do not have a high degree of this private incentive, a collective 
government arrangement at a regional, federal, or even world level could be appropriate.

Deutsch et al. (1984) explain however that although there are spatial spillovers in crime which require some central international or national systems, as with the DNA databanks described in Doleac (2012) or with the international police organization Interpol, most criminals operate regionally. McAndrew (2012a) therefore suggests that the degree to which criminals operate

regionally rather than nationally or even globally will determine how concentrated the benefits of criminal DNA analysis are to the jurisdiction providing them and thus how private or public this output behaves. If the external benefits of DNA analysis to those outside the jurisdiction a forensic laboratory serves are small and decreasing with distance, these benefits may be inframarginal and not affect the optimal output and consumption decision of a jurisdiction.

\subsection{The Benefits of DNA Tests}

Before describing the benefits of DNA analysis, it is important to distinguish between DNA analysis versus DNA databanks. DNA analysis refers to the act of collecting evidence from a crime scene or victim and processing it through a laboratory in order for a forensic scientist to write a case report regarding the determination of a DNA profile. These tests require physical resources to produce and a laboratory analyst's time, and in that sense are rival and excludable. DNA databanks alternatively, as described by Doleac (2012), are a group of DNA profiles, including those of criminal offenders, who have had their DNA collected in the past. When future crimes occur, new DNA collected could be compared to the profiles in a DNA databank to quickly identify the criminals. As the number of DNA databank profiles grow, the probability that a profiled criminal is punished for subsequent crimes or that an innocent individual is exonerated grows. The information contained in DNA databanks is easily shared at low cost and is thus nonrival, and also experiences enormous economies to scale (Doleac 2012). 
In that sense DNA profiles are likely more public than private goods and ought to be provided by countries if not a global organization. Although individual DNA analysis is required to create a DNA databank profile, DNA analysis uses resources which do experience congestion. A DNA test kit or a laboratory technician's time are limited, and cannot be shared in a limitless way. Information from those tests however can be shared at low costs which is the important distinction.

DNA analysis, which is the focus of this paper, has proved to be a powerful tool used in modern crime scene investigation to both convict criminals and exonerate the innocent since the 1980s. In most cases, the benefits of evidence collection from criminal DNA analysis cannot be internalized by an individual, but rather are internalized by a sharing group of people such as a city or county who collectively receive a higher level or sense of safety and justice. For example, it is likely that a rapist convicted in the U.K. has no positive external benefit to those living in California. However, it is likely that a rapist convicted in New York creates a positive benefit in New Jersey due to their proximity to one another. Thus, a forensic laboratory service area that can contain any external benefits and determine demand behavior likely does not need to be as large as the entire world or even a country, but would be the size of regions or small countries that a representative criminal tends to operate in. McAndrew (2012a) therefore claims that DNA analysis is not a purely private or public good, but rather behaves as a club good whose consumption is shared by a discrete number of people (Buchanan 1965). It is true that clubs or sharing groups who pay for DNA analysis may occasionally cause external benefits for neighboring regions that do not pay for this testing, but external benefits are only a market failure if consumption decisions of the club are altered as a result. If a club is able to fully internalize the marginal benefits of criminal DNA testing, the external benefits to those who do 
not pay may be inframarginal and any government action could not make a Pareto improving movement.

To better clarify the difference between inframarginal benefits that are not Paretorelevant and benefits that truly cause market failure, consider Figure 2.3. Figure 2.3 illustrates the construction of the marginal social benefit curve, which is derived by the summation of the private demand curve for DNA testing and the marginal external benefit curve, which represents the positive externality that results from this testing. The optimal provision of DNA analysis is determined, as with any good, by the intersection of the marginal social benefit curve D' and a marginal social cost curve MC (Sobel 2004). For simplicity MC is assumed to be constant.

Case A depicts a situation where marginal external benefits cannot be contained privately and every unit of output creates an external benefit, EB, to surrounding populations. In this case the marginal social benefit curve D' is shifted up parallel to the private demand curve D by the addition of the external benefits EB. This is a classic depiction of market failure. Privately, output level Q1, at the intersection of D and MC, is less than the socially optimal level of output $\mathrm{Q}^{*}$, found at the intersection of $\mathrm{D}^{\prime}$ and $\mathrm{MC}$. The market failure occurs because there is no charge for the positive benefit EB. Alternatively, Case B depicts the opposite situation where there are no external benefits and all benefits are represented by the individual demand curve such that $\mathrm{D}=\mathrm{D}$ '. In this case the marginal social benefit curve equals private demand and there is no market failure to correct. Finally, Case $\mathrm{C}$ depicts a situation where external benefits exist at small levels of output, but past some level these benefits become inframarginal and would not affect the optimal level of DNA testing consumption. Note that if the marginal cost curve MC were very high, or if the private demand curve D shifted far enough towards the origin, or if the external benefit curve EB shifted far enough right, the externality affect may become Pareto- 
relevant if the intersection between MC and D' occurs at a higher level of output compared to the intersection between MC and D. This situation would lead to an outcome similar to Case A, which depicts a market failure.

\subsection{The Median Voter Model}

To test whether there is congestion in criminal DNA analysis, as shown in Case A, a median voter model is employed to estimate a demand function. The median voter model originated from Bowen (1943) and was expanded by Downs (1957) and Black (1958) as a way to explain the behavior of governments by assuming that politicians work towards granting the desires of the median voter. Versions of this model have also been used as an empirical framework to test for the degree of publicness (or privateness) of other goods, including Borcherding and Deacon (1972) and Bergstrom and Goodman (1973), Deno and Mehay (1987), Holcombe and Sobel (1995), King (2007), and Mathers (2009) who analyzed the publicness of various municipal outputs, state legislation, K-12 education, and AIDs prevention respectively.

Since forensic science budgets are largely determined in a political framework, and voters in this framework are interested in the quality of criminal justice in their jurisdiction, a median voter can be assumed to control forensic output through voting. This model is therefore appropriate and, according to Congleton and Shughart (1990) and Congleton and Bennett (1995), ought to perform better than alternative special interest group models since forensic science is a large scale public program which generally affects everyone.

In this model, a parameter representing the degree of congestion is estimated by analyzing how the marginal social benefit curves are developed. With purely private goods, the marginal benefit curves of market participants horizontally sum to the market demand curve, implying that an increase in consumers would shift demand to the right and increase the 
equilibrium level of output. Alternatively, with purely public goods the marginal benefit curves of all market participants are vertically summed to the marginal social benefit curve (Sobel 2004). Public goods have vertically summed marginal benefit curves since they are nonrival or joint in consumption, and the addition of consumers does not theoretically affect the equilibrium level of output, but rather affects total social value. The classic example which illustrates this distinction is a missile defense shield, where output of missile defense need not rise as populations rise, however its social value increases as the population it serves grows.

Formally, we assume that the decisive or median voter's utility function $U$ is represented as

$$
\mathrm{U}_{\mathrm{ij}}=\mathrm{U}_{\mathrm{ij}}\left(\mathrm{X}_{\mathrm{ij}}, \mathrm{f}_{\mathrm{ij}}\right)
$$

where $f_{i j}$ is the quantity of forensic science DNA services consumed by the median voter $i$ in jurisdiction $\mathrm{j}$, and $\mathrm{X}_{\mathrm{ij}}$ is the quantity of all other goods consumed. The variable $\mathrm{f}_{\mathrm{ij}}$ represents a portion of the total output of forensic science DNA services $F_{j}$ and can be defined as

$$
\mathrm{f}_{\mathrm{ij}}=\mathrm{N}_{\mathrm{j}}^{-\gamma} \mathrm{F}_{\mathrm{j}}
$$

where $\mathrm{N}_{\mathrm{j}}$ represents the population in a jurisdiction which shares $\mathrm{F}_{\mathrm{j}}$, and $\gamma$ is the congestion parameter. If forensic science DNA services are purely public goods $\gamma=0$, which implies $f_{i j}=F_{j}$ and the optimal provision of $F_{j}$ should not be affected by population. If forensic science DNA services are purely private goods $\gamma=1$, indicating each individual's consumption of forensic science services would be proportional to their share in the total population and any increase in population would increase the required level of $F_{j}$.

When maximizing (2.1) the median voter faces a budget constraint of

$$
Y_{i j}=P_{x} X_{i j}+T_{i j} P_{F j} F_{j}
$$


where $Y_{i j}$ is the median voter's disposable income, $P_{X}$ is the price of goods $X_{i j}, P_{F j}$ is the price of consuming one unit of $\mathrm{F}_{\mathrm{j}}$, and $\mathrm{T}_{\mathrm{ij}}$ is the median voter's tax price.

By substituting (2.2) into (2.3), the budget constraint can be rewritten as

$$
Y_{i j}=P_{X} X_{i j}+T_{i j} P_{F j} f_{i j} N_{j}^{\gamma}
$$

which through optimization techniques yields the demand equation

$$
f_{i j}=f_{i j}\left(P_{X}, T_{i j}, P_{F j}, N_{j}, Y_{i j}\right) \text {. }
$$

It is assumed that $\mathrm{P}_{\mathrm{X}}$ is the same across jurisdictions for simplicity. $\mathrm{P}_{\mathrm{Fj}}$ can also be assumed constant, however this can be relaxed with the addition of other variables that account for differences in prices of forensic science across jurisdictions or by using dissaggregated count data for $\mathrm{f}_{\mathrm{ij}}$ which is done in this paper. Assuming a constant price elasticity type multiplicative demand equation and the vector $\mathrm{A}$ which represents differences in tastes across jurisdictions generates

$$
f_{i j}=A\left(T_{i j} N_{j}^{\gamma}\right)^{\alpha} Y_{i j}^{\lambda}
$$

By substituting (2.2) into (2.6), the total demand equation for forensic science DNA services can be represented by

$$
F_{i j}=A T_{i j}^{\alpha} N_{j}^{\gamma(1+\alpha)} Y_{i j}^{\lambda}
$$

or

$$
F_{i j}=A T_{i j}^{\alpha} N_{j}^{\theta} Y_{i j}^{\lambda}
$$

where $\theta=\gamma(1+\alpha)$, and implies that the total demand of forensic science DNA services is increasing in population if $\gamma$ is positive.

Taking natural logs, the median voter's demand equation for the total level of forensic science DNA service output in a jurisdiction can be written as 


$$
\ln \mathrm{F}_{\mathrm{ij}}=\ln \mathrm{A}+\alpha \ln \mathrm{T}_{\mathrm{ij}}+\theta \ln \mathrm{N}_{\mathrm{j}}+\lambda \ln \mathrm{Y}_{\mathrm{ij}}
$$

where $Y_{\mathrm{ij}}$ or disposable median income is calculated in the following manner.

$$
Y_{i j}=Y_{i j}^{*}+G_{j} N_{j}^{-1}-T_{G} Y_{i j}
$$

In equation (2.10) $Y_{\mathrm{ij}}^{*}$ represents gross median income, $\mathrm{G}_{\mathrm{j}}$ represents the total amount of federal grants to the jurisdiction, $\mathrm{G}_{\mathrm{j}} \mathrm{N}_{\mathrm{j}}^{-1}$ therefore represents the median voter's share of the federal grants assuming it is proportional to their share in the population, and $\mathrm{T}_{\mathrm{G}}$ is the median voter's effective federal tax rate and thus $T_{G} Y_{i j}$ is the median voter's federal tax liability.

The parameter A represents the differences across states of the median voter's preferences not explicitly shown in the theoretical model. Preference differences derive from political, cultural, and social factors which differ by state. To develop an empirical model these preferences are more explicitly represented by using a jurisdiction's geographic size (GEOG), median age (AG), and percent white (W). Ceteris paribus, larger geographic sizes require greater spending on public goods, therefore geographic size is expected to be positively related to demand. Age is expected to be positively related to output as well since older people normally demand more public services, which is consistent with the lifecycle income hypothesis (Ando and Modigliani 1963). Finally, percent white is included to capture a possible demographic effect on the demand for forensic science. Crime, and thus forensic science services, is often explained by race.

There are a large number of studies within this literature that use population density rather that geographic size as an explanatory variable for various local public goods (Deno and Mehay (1987), Holcombe and Sobel (1995), King (2007), and Mathers (2009)). The reason for population density's inclusion in this literature has been to acknowledge that public service output tends to rise as populations rise but at a decreasing rate due to the benefits of economies 
of scale. This connection results in a negative relationship between population density and output. However, using population density necessarily leads to multicollinearity issues since the $\log$ of population density equals the log of population minus the log of geographic size as shown in equation (2.11).

$$
\ln (\text { population density })=\ln \left(\frac{\mathrm{N}}{\mathrm{GEOG}}\right)=\ln (\mathrm{N})-\ln (\mathrm{GEOG}) .
$$

Population density consequently includes a redundancy with population, which is already included in equation (2.9). The effect of population density therefore cannot be truly captured since any estimate of population density assumes population will simultaneously be held constant. The resulting coefficient estimate of population density will therefore capture only the effect of GEOG. Although this redundancy does not necessarily bias results or affect $\mathrm{R}^{2}$, it can lead to imprecise and unreliable estimates of the directly specified population parameter. With multicollinearity, typically one of the correlated variable's coefficient is estimated to be too high, and the other to be estimated too low. ${ }^{4}$ The direction of this error can change erratically with a modification of specification or data (Wooldridge 2009). Density is included in the results section of this paper for comparison.

For a similar reason the crime rate, which ought to be a driving factor of forensic science output, is excluded given that the log of the crime rate reduces to the log of total crime minus the $\log$ of population. Total crime was considered as a possible alternative to the crime rate; however total crime is highly correlated to population which would still cause multicollinearity issues if included. Thus, the median voter's demand equation can be written as

\footnotetext{
${ }^{4}$ In this specific case it is important to note that the second population term which is indirectly included is the problem variable, not density itself. Since the second population term is not directly included, the only visible effect of a multicollinearity issue is on the first population parameter. When a regression is run, population density reduces to $1 /$ (geographic area) since population is held constant by the first population argument.
} 


$$
\ln F_{i j}=\beta_{1}+\beta_{2} \ln T_{i j}+\beta_{3} \ln N_{j}+\beta_{4} \ln Y_{i j}+\beta_{5} \operatorname{lnGEOG} G_{j}+\beta_{6} \ln A G_{j}+\beta_{7} \ln W_{j}+\varepsilon_{i j} .
$$

where $\varepsilon_{\mathrm{ij}}$ is the error term.

It is convention in this type of empirical model to proxy for $F_{i j}$ by using aggregate expenditure data on the level of spending of this local public good. As Oates (1988) describes however, expenditure data does not capture the differences in demand between large and small jurisdictions, leading to an upward bias in estimated congestion parameters. The current application of this model therefore takes advantage of disaggregated count data on individual DNA reports, DNA cases, DNA tests, and DNA samples produced in each jurisdiction which accounts for the level and range of this output. ${ }^{5}$ This better represents consumption bundle differences across jurisdictions and is an improvement from the convention of a proxy. Capturing the range effects of this output is important since the ratio of these four subfunctions of DNA analysis change in a predictable manner from small to large jurisdictions. Moreover, by using count data the assumption that $\mathrm{P}_{\mathrm{Fj}}$ in equation (2.5) is constant across jurisdictions is perfectly relaxed which is a more realistic approach since the prices of DNA analysis varies widely based upon the individual characteristics of the jurisdiction considered. Large jurisdictions for example typically pay higher salaries to operational and supervisory staff due to the higher costs of living. Since staffing typically makes up $70-80 \%$ of a forensic science laboratory's budget (Heames 2011), ignoring price differences across jurisdictions would also

\footnotetext{
${ }^{5}$ The definition of a report, case, test, and sample are as follows: Report: A formal statement of the results of an investigation, or of any matter on which definite information is required, made by some person or body instructed or required to do so.

Case: A request from a crime lab "customer" that includes forensic investigations in one or more investigative areas Test: An analytical process including, but not limited to, visual examination, instrumental analysis, presumptive evaluations, enhancement techniques, extractions, quantifications, microscopic techniques, and comparative examinations. This does not include technical or administrative reviews.

Sample: An item of evidence or a portion of an item of evidence that generates a reported result.
} 
ignore the "zoo effect" if a greater range of all service provided in a jurisdiction leads to higher costs of living.

\subsection{Data and Empirical Results}

Equation (2.12) is estimated using DNA analysis output data from the National Institute of Justice's newly developed project FORESIGHT, which is a business evaluation system for forensic science laboratories operating not only in the U.S. but also internationally (Houck et al. 2009). The Census of Public Crime Laboratories and the International Association for Identification Forensic Service Providers Survey also collects information on forensic laboratories, however FORESIGHT improves upon these datasets by giving greater detail and standardization of laboratory definitions. There are 65 laboratories that voluntarily participated in FORESIGHT in 2010-2011 which include local, state, and country level laboratories. ${ }^{6}$ A comparison of FORESIGHT with the Census of Public Crime Laboratories suggests selection bias is not an issue. Only U.S. state laboratories are used in the present analysis to avoid omitted variable bias and having to deal with institutional differences across countries. Data on the explanatory variables other than that from FORESIGHT are from the U.S. Bureau of the Census. Descriptive statistics are shown in Table 2.1. The congestion parameter $\gamma$ is calculated as $\gamma=\theta(1+\alpha)^{-1}=\beta_{3}\left(1+\beta_{2}\right)^{-1}$, where $\beta_{3}$ and $\beta_{2}$ are the estimated elasticities of forensic science output (either count or expenditure) with respect to population and the median voter's tax price.

In order to determine whether Oates' "zoo effect" exists, specification [1], [2], and [3] in Table 2.2 estimate demand equations using the aggregate expenditure of DNA analysis as proxy for output as an initial benchmark for comparison. Using ordinary least squares estimation, the

\footnotetext{
${ }^{6}$ Laboratories that participate in the FORESIGHT project are given anonymity as a condition for participation and will therefore not be listed or discussed.
} 
estimated elasticities in specifications [1] through [3] are consistent with the aforementioned studies. The tax price elasticity is negative and significant which implies a downward sloping demand curve, that as costs rise, demand for forensic science services fall. The population and disposable income elasticity coefficients are positive and significant suggesting that forensic science services rise with population growth and that forensic science output is a normal good whose consumption rises with wealth. The estimated geographic area elasticity is positive and significant, suggesting larger areas consume higher amounts of output. As explained previously, population density contains no new information compared to geographic area, and is consequently estimated to have the same effect but with the opposite sign as geographic area. However, the effect from including the redundant population parameter contained within population density has caused the directly specified population elasticity estimate to rise, which results in an overestimation of the congestion parameter as well. The elasticity of age coefficient is positive and is consistent with the literature and lifecycle income hypothesis that older people demand more government provided goods. Finally the elasticity coefficients of percent white was not significant, however the signs on percent white supports the findings of King (2007).

The estimated congestion parameter $\gamma$ in specifications [1] through [3] is estimated to be between 3.25 and 6.14. A Wald test on the linear restriction $\mathrm{H}_{0}: \beta_{2}-\beta_{3}=-1$ was run for all specifications to test whether $\gamma=1$, or that DNA test reports are pure private goods. Similarly the linear restriction that $\gamma$ is different from zero, or $\mathrm{H}_{0}: \beta_{3}=0$, was tested using the normal $\mathrm{t}$ test on the population coefficient to determine whether $\gamma=0$ and DNA test reports are purely public goods. These tests suggest that the results from the specifications using expenditure data behave as expected compared to the previous literature. Similar to Deno and Mehay (1987) and King (2007) who study municipal output and K-12 education respectively, the calculated $\gamma$ in 
this study can be calculated greater than one, and according to the Wald test is statistically greater than one in specification [3]. If taken at face value this suggests that DNA analysis contains a high degree of congestion and is not a public good. Demand decision would thus be more appropriately determined by individuals if this estimate of $\gamma$ is assumed correct.

Using aggregated expenditure data as a proxy for output however does not account for changing consumption bundles as the size of a jurisdiction changes. To see if the "zoo effect" exists and has an effect on the estimated congestion parameter, a Poisson regression is run on the unit count output of DNA reports, DNA test, DNA case, and DNA samples in specifications [4] through [15] displayed Tables 2.3 through Table 2.6. This count data improves upon expenditure data as it accounts for the range of outputs within DNA analysis, and perfectly controls for predictable price difference across jurisdictions. A Poisson regression is used instead of ordinary least squares since it is more appropriate for count data that contains different distributional characteristic than continuous data. ${ }^{7}$ To protect against an underestimation of standard errors common in Poisson models when count data exhibits over-dispersion ${ }^{8}$, robust standard errors are used (Cameron and Trivedi 2009). Using the robust standard errors, a ChiSquare test is run that suggests that over-dispersion does not bias the results.

The elasticity estimates using disaggregated count data in specifications [4] through [15] are similar to specifications [1] through [3] in sign and significance. However, as expected Oates" "zoo effect" does appear to exist. When disaggregated count data is used to account for demand differences across jurisdictions, the congestion parameters are estimated to be

\footnotetext{
${ }^{7}$ Ordinary least squares estimation assumes continuous variables, which would be inappropriate for count data that is not continuous.

${ }^{8}$ Over-dispersion in count data occurs when the variance of the count exceeds the expected value of the count. This may cause Poisson models to underestimate standard errors and thus result in a surprisingly large number of statistically significant coefficients. Using robust standard errors helps to control for the mild violating assumptions caused by over-dispersion.
} 
significantly lower. Specifically, the estimated $\gamma$ is between 0.12 and 0.18 for DNA reports, 0.08 and 0.10 for DNA tests, 0.11 and 0.16 for DNA cases, and 0.10 and 0.15 for DNA samples. Due to the nature of the Poisson regression model and its distributional assumptions, the Pseudo-Rsquared term is listed rather than R-squared, and the test on the linear restriction $\mathrm{H}_{0}: \beta_{2}-\beta_{3}=$ -1 uses the Chi-Square test rather than Wald test. It is shown using the Chi-Square test that $\gamma$ is statistically less than 1 . It is also shown using the t-test on the population coefficient that $\gamma$ is statistically greater than 0 which implies that forensic science is indeed a club good as suggested by McAndrew (2012a). DNA analysis thus contains significantly less congestion compared to what specifications [1] through [3] imply given that aggregated expenditure data does not account for changing consumption bundles or demand differences across jurisdictions. Accordingly, demand decisions for the level of forensic science to consume are more appropriately determined by groups and not individuals. Intuitively this makes more sense. Individuals cannot be expected to determine how many criminal DNA tests they ought to consume and thus are run in order to convict a criminal or exonerate the innocent.

\subsection{Conclusion and Policy Recommendation}

The influential papers by Borcherding and Deacon (1972) and Bergstrom and Goodman (1973) inspired an outpouring of empirical research which estimated demand functions for a wide array of local public outputs. These studies have largely suggested that many local public outputs have a high degree of congestion and are thus private goods. Oates (1988) however suggests this common finding has come through a methodological weakness in the measurement of demand by ignoring the "zoo effect" which would cause an upward bias on the measurement of congestion, and not as a result of economic reasoning or forces. By analyzing the demand for DNA analysis using aggregated expenditure data to proxy for output and also the disaggregated 
count level data on various components of DNA analysis, this paper has given empirical support for the existence of the "zoo effect." Disaggregated count data accounts for the range of output differences across jurisdictions, and also accounts for the price differences that predictably occur. Thus, when count data is used, which accounts for the "zoo effect", significantly lower congestion parameters for DNA analysis output are estimated which suggests that DNA analysis is not a private good, but rather a club good as suggested by McAndrew (2012a). Demand decisions for DNA analysis should thus occur at some group level, perhaps by regions or small countries, and not by individuals. This result seems obvious, since groups, and not individuals, determine the output of criminal justice in general. Oates' skepticism then seems right, in that local public outputs may contain a great deal less congestion than previous estimates have found. This finding implies nothing in regards to the supply side decisions of local public outputs. Communities can still decide to produce DNA analysis through government options, privatization, public-private partnerships, insourcing, outsourcing, etc., by using whatever criteria the community determines to be advantageous. Future research on the economies of scale and the economies of scope in the forensic science industry will be able to shed light on this, and determine in what way this output can be efficiently and effectively supplied. Indeed, the lighthouses described in Coase (1974) is an example of a public good that was successfully supplied privately. There is no contradiction, however this nuance is often overlooked. 


\section{Figure 2.1: Expenditure on "Parks and Recreation"9}

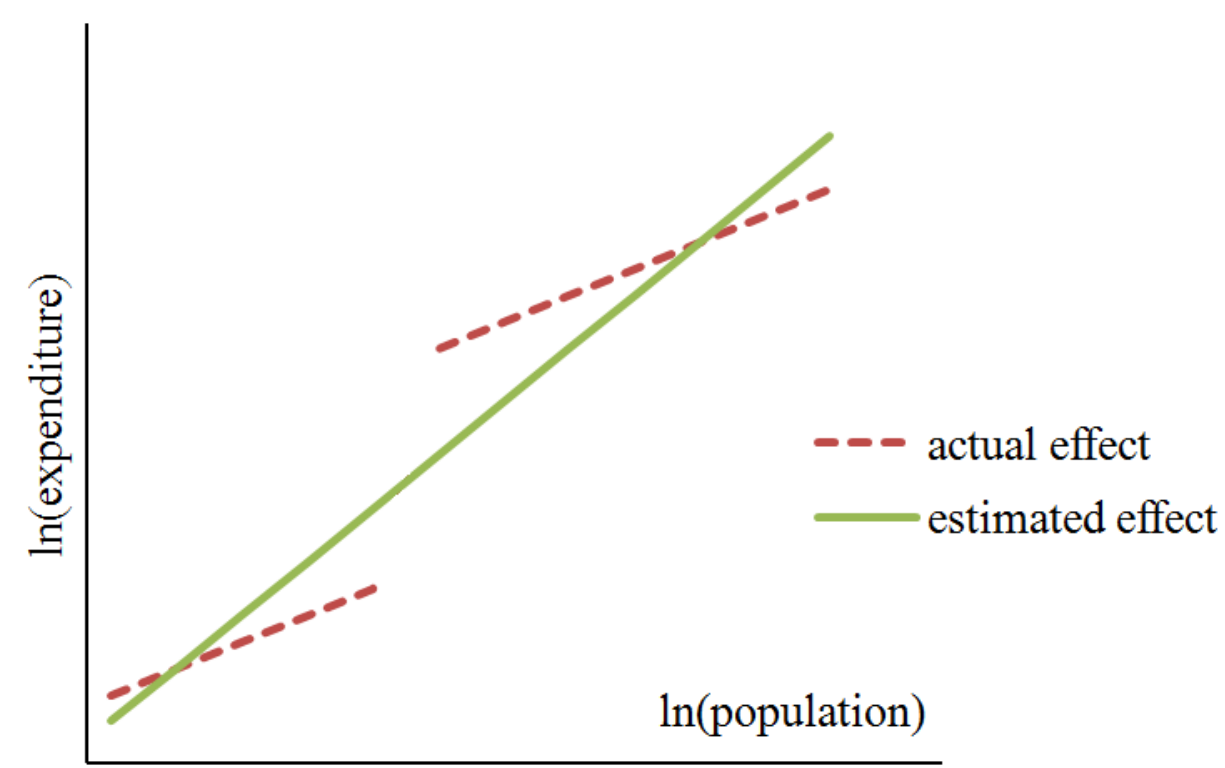

\footnotetext{
${ }^{9}$ Figure 2.1 illustrates the discontinuities that some local public outputs experience. A zoo for example would entail a very large increase in local public expenditures for the first unit of production. If aggregate data on "parks and recreation" were used to estimate demand rather that disaggregated data on the components of this aggregated output, an estimate of population's effect on expenditure would be upwardly bias. The range and not just level of outputs is thus an important factor in an estimate of demand.
} 


\section{Figure 2.2: Population versus Output ${ }^{10}$}

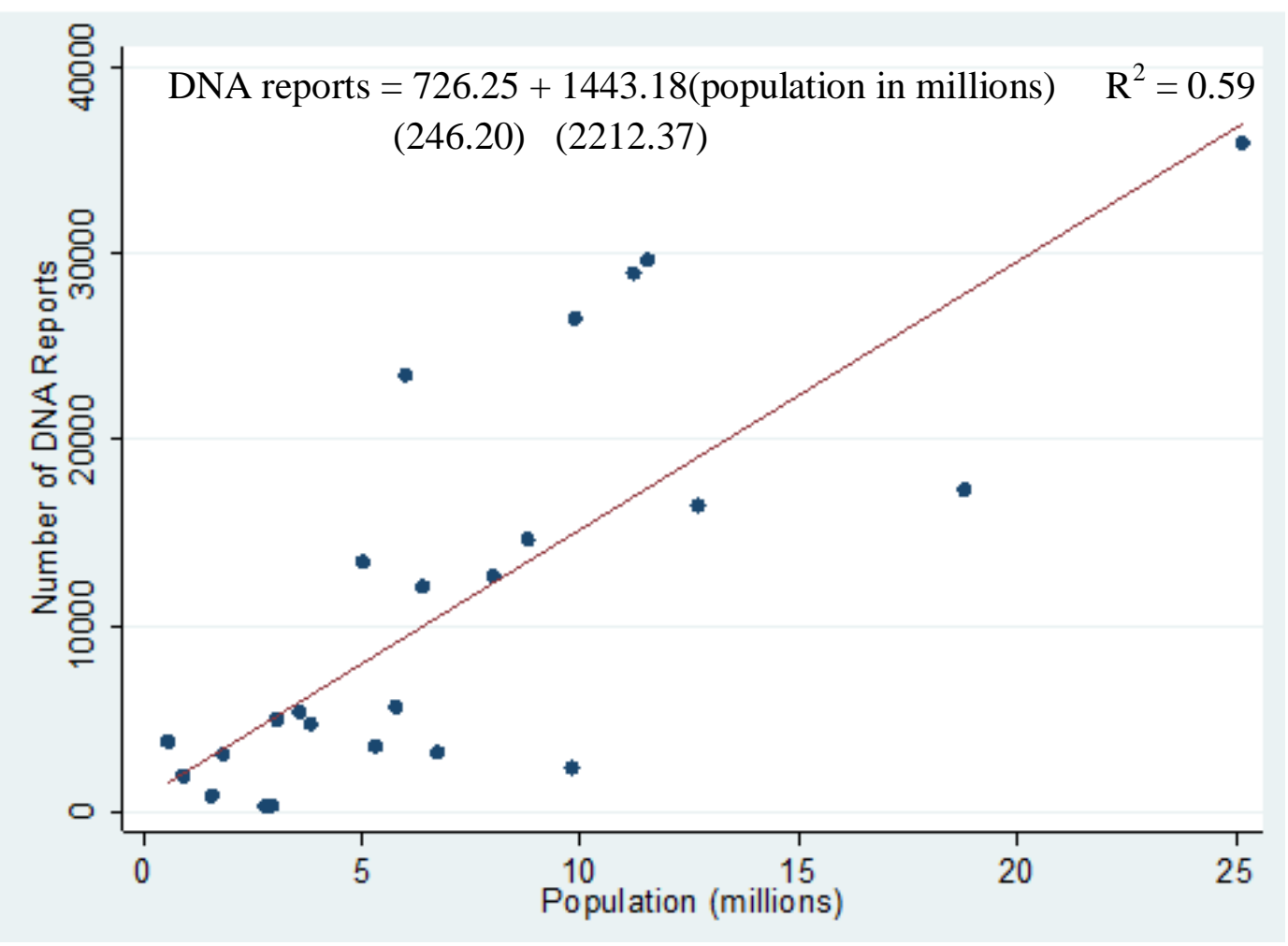

${ }^{10}$ Figure 2.2 shows the positive relationship between population and the number of DNA reports produced in a jurisdiction as recorded by the FORESIGHT dataset. The apparent positive relationship suggests that some congestion in consumption exists. The numbers in parenthesis in the equation within Figure 2.2 are standard errors. 
Figure 2.3: Deriving the Social Marginal Benefit Curve ${ }^{11}$

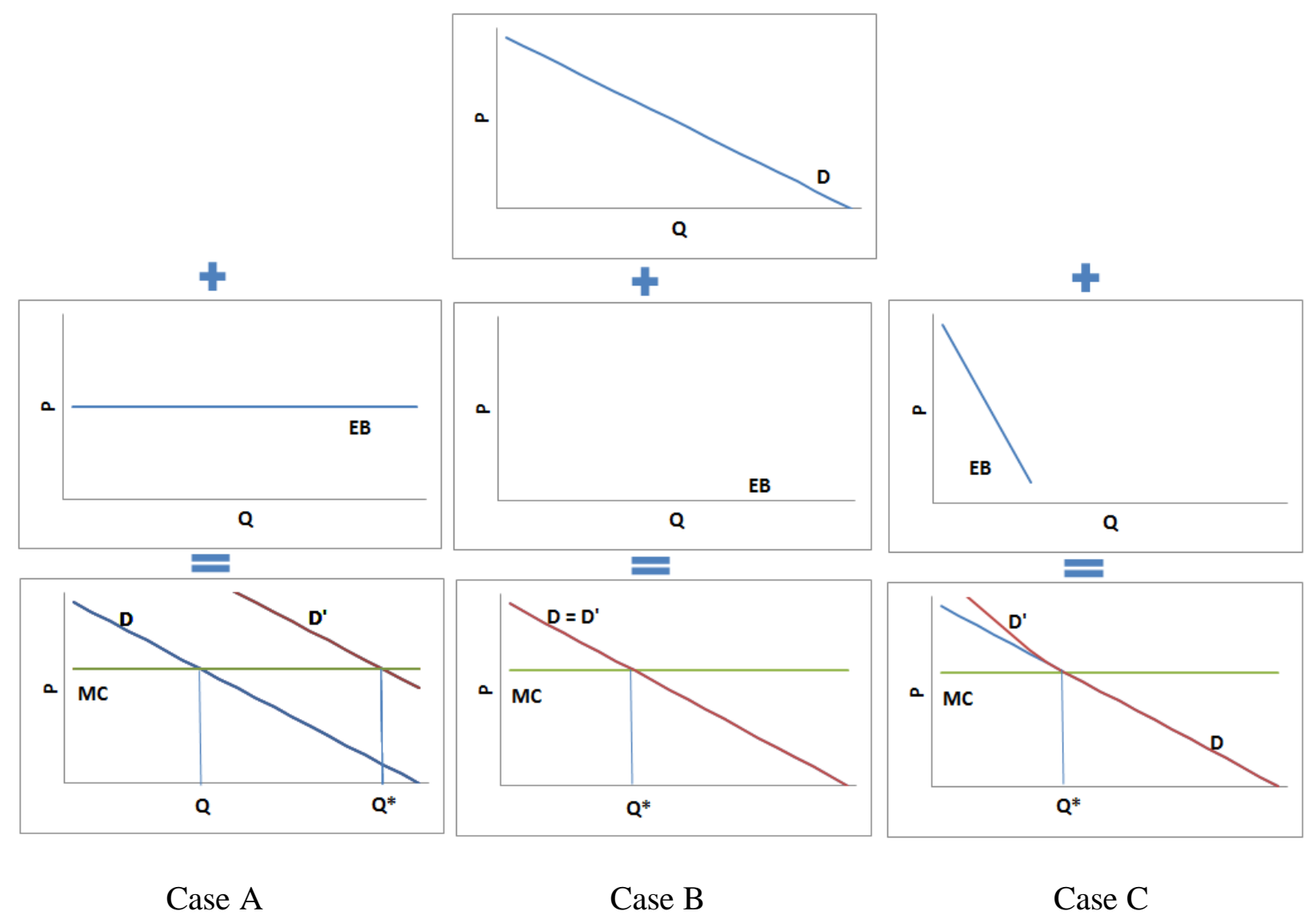

\footnotetext{
${ }^{11}$ Figure 2.3 displays the construction of the social marginal benefit curve in three different scenarios. Case A depicts a scenario where external benefits (EB) exist and the socially optimal output of Q* is not reached because the external benefits cannot be charged for, resulting in market failure. Case B depicts a situation where there are no external benefits, and the social marginal benefit curve equals private demand resulting in the socially optimal level of output to be consumed. Case $\mathrm{C}$ shows a situation with inframarginal externalities, where although there exists external benefits at a low level of output, this externality does not result in market failure. The socially optimal level of output is thus reached at sufficiently high levels of consumption.
} 
Table 2.1: Descriptive Statistics ${ }^{12}$

\begin{tabular}{crrrr}
\hline Variable & \multicolumn{1}{c}{ Mean } & \multicolumn{1}{c}{ Std. Dev. } & \multicolumn{1}{c}{ Min } & \multicolumn{1}{c}{ Max } \\
\hline DNA Total Expenditures & $\$ 11,130,792.02$ & $\$ 12,033,833.42$ & $\$ 772,602.00$ & $\$ 40,729,399.62$ \\
Count of DNA Reports & $10,832.48$ & $10,717.08$ & 270 & 35,943 \\
Count of DNA Tests & $50,341.20$ & $47,408.18$ & 2,284 & 147,413 \\
Count of DNA Cases & $4,893.99$ & $4,345.40$ & 231 & 14,601 \\
Count of DNA Samples & $41,374.09$ & $42,337.74$ & 926 & 132,722 \\
Effective Median Tax Rate & 0.03 & 0.01 & 0.02 & 0.04 \\
Population & $7,002,734$ & $5,747,539$ & 563,626 & $25,145,561$ \\
Disposable Income & $\$ 50,443.22$ & $\$ 7,868.56$ & $\$ 36,065.63$ & $\$ 67,257.75$ \\
Geographic Size (sq mile) & $69,986.06$ & $51,823.44$ & $2,489.27$ & $268,580.80$ \\
Population Density & 187.25 & 231.27 & 5.76 & $1,008.09$ \\
Median Age & 37.14 & 2.38 & 29.20 & 40.70 \\
Percent White & 0.77 & 0.10 & 0.58 & 0.91 \\
\hline
\end{tabular}

${ }^{12}$ Table 2.1 describes a 2010-2011 National Institute of Justice FORESIGHT cross section dataset on DNA expenditures, reports, cases, tests, and samples. This dataset contains laboratories from the U.S. and internationally. Only state laboratories are used in analysis and are included in the descriptive statistics. Other demographic data comes from the U.S. Bureau of the Census. 
Table 2.2: 2010 OLS Cross Section Estimate of Total DNA Expenditure ${ }^{13}$

$[1] \quad[3]$

\begin{tabular}{|c|c|c|c|}
\hline Independent Variable & & & \\
\hline $\ln ($ Tax Price $)$ & $\begin{array}{l}-0.7245 \\
(0.5865)\end{array}$ & $\begin{array}{c}-0.8256 * * \\
(0.4632)\end{array}$ & $\begin{array}{c}-0.8256 * * \\
(0.4632)\end{array}$ \\
\hline $\ln ($ Population $)$ & $\begin{array}{c}0.8944 * * * \\
(0.2154)\end{array}$ & $\begin{array}{c}0.6645 * * * \\
(0.1724)\end{array}$ & $\begin{array}{c}1.0708 * * * \\
(0.1464)\end{array}$ \\
\hline $\ln$ (Disposable Income) & & $\begin{array}{c}2.6429 * * * \\
(0.7414)\end{array}$ & $\begin{array}{c}2.6429 * * * \\
(0.7414)\end{array}$ \\
\hline $\ln ($ Geographic Area $)$ & & $\begin{array}{c}0.4062 * * * \\
(0.1304)\end{array}$ & \\
\hline $\ln ($ Population Density) & & & $\begin{array}{c}-0.4062 * * * \\
(0.1304)\end{array}$ \\
\hline $\ln ($ Median Age $)$ & & $\begin{array}{c}8.0939 * * * \\
(2.0520)\end{array}$ & $\begin{array}{c}8.0939 * * * \\
(2.0520)\end{array}$ \\
\hline $\ln ($ Percent White $)$ & & $\begin{array}{c}0.2493 \\
(0.8863)\end{array}$ & $\begin{array}{c}0.2493 \\
(0.8863)\end{array}$ \\
\hline Constant & $\begin{array}{l}-0.7920 \\
(3.4717)\end{array}$ & $\begin{array}{c}-59.7681 * * * \\
(9.8532)\end{array}$ & $\begin{array}{c}-59.7681 * * * \\
(9.8528)\end{array}$ \\
\hline$\gamma($ congestion parameter) & 3.2463 & 3.8112 & 6.1396 \\
\hline R-squared & 0.5309 & 0.7728 & 0.7728 \\
\hline Wald statistic $(\mathrm{H} 0: \beta 2-\beta 3=-1)$ & 1.19 & 0.97 & $3.29 * *$ \\
\hline
\end{tabular}

${ }^{13}$ Table 2.2 estimates a demand function of DNA analysis using expenditure as a proxy for output. Elasticities are listed in this table, with the congestion parameter being calculated as the population elasticity divided by 1 plus the tax price elasticity. Statistical significance of $10 \%, 5 \%$, and $1 \%$ are represented by $*, * *$, and $* * *$ respectively. Robust standard errors are in parenthesis. The results in this table suggest that DNA analysis contains congestion and is thus a private good. 
Table 2.3: 2010 Poisson Cross Section Estimate of Unit Level DNA Report Output ${ }^{14}$

\begin{tabular}{|c|c|c|c|}
\hline & [4] & [5] & [6] \\
\hline Independent Variable & & & \\
\hline $\ln ($ Tax Price $)$ & $\begin{array}{l}-0.1793 * \\
(0.1118)\end{array}$ & $\begin{array}{c}-0.2518 * * * \\
(0.0674)\end{array}$ & $\begin{array}{c}-0.2518 * * * \\
(0.0674)\end{array}$ \\
\hline $\ln$ (Population) & $\begin{array}{c}0.1122 * * * \\
(0.0312)\end{array}$ & $\begin{array}{c}0.0874 * * * \\
(0.0199)\end{array}$ & $\begin{array}{c}0.1367 * * * \\
(0.0169)\end{array}$ \\
\hline $\ln$ (Disposable Income) & & $\begin{array}{c}0.4582 * * * \\
(0.0996)\end{array}$ & $\begin{array}{c}0.4582 * * * \\
(0.0996)\end{array}$ \\
\hline $\ln$ (Geographic Area) & & $\begin{array}{c}0.0493 * * * \\
(0.0166)\end{array}$ & \\
\hline $\ln$ (Population Density) & & & $\begin{array}{c}-0.0493 * * * \\
(0.0166)\end{array}$ \\
\hline $\ln ($ Median Age $)$ & & $\begin{array}{c}1.4356 * * * \\
(0.3985)\end{array}$ & $\begin{array}{c}1.4356^{* * * *} \\
(0.3985)\end{array}$ \\
\hline $\ln ($ Percent White $)$ & & $\begin{array}{c}0.2767 * * * \\
(0.0929)\end{array}$ & $\begin{array}{c}0.2767 * * * \\
(0.0929)\end{array}$ \\
\hline Constant & $\begin{array}{l}-0.2382 \\
(0.5663) \\
\end{array}$ & $\begin{array}{c}-10.7261 * * * \\
(1.6169)\end{array}$ & $\begin{array}{c}-10.7261 * * * \\
(1.6168) \\
\end{array}$ \\
\hline$\gamma($ congestion parameter) & 0.1367 & 0.1168 & 0.1827 \\
\hline Pseudo-R-squared & 0.0272 & 0.0483 & 0.0483 \\
\hline Chi $^{\wedge} 2(\mathrm{H} 0: \beta 2-\beta 3=-1)$ & $42.37 * * *$ & $85.46^{* * *}$ & $71.89 * * *$ \\
\hline
\end{tabular}

\footnotetext{
${ }^{14}$ Table 2.3 estimates a demand function of DNA reports using the unit count as a measure of output. Elasticities are listed in this table, with the congestion parameter being calculated as the population elasticity divided by 1 plus the tax price elasticity. Statistical significance of $10 \%, 5 \%$, and $1 \%$ are represented by $*, * *$, and $* * *$ respectively. Robust standard errors are in parenthesis. The results in this table suggest that DNA analysis contains a low degree of congestion, implying a club good and not a private good.
} 
Table 2.4: 2010 Poisson Cross Section Estimate of Unit Level DNA Test Output ${ }^{15}$

$[7] \quad[8] \quad[9]$

\begin{tabular}{|c|c|c|c|}
\hline Independent Variable & & & \\
\hline $\ln ($ Tax Price $)$ & $\begin{array}{l}-0.1362^{*} \\
(0.0794)\end{array}$ & $\begin{array}{c}-0.1692 * * \\
(0.0850)\end{array}$ & $\begin{array}{c}-0.1692 * * \\
(0.0850)\end{array}$ \\
\hline $\ln ($ Population $)$ & $\begin{array}{c}0.0798 * * * \\
(0.0205)\end{array}$ & $\begin{array}{c}0.0628 * * * \\
(0.0174)\end{array}$ & $\begin{array}{c}0.0857 * * * \\
(0.0220)\end{array}$ \\
\hline $\ln ($ Disposable Income $)$ & & $\begin{array}{c}0.1638 \\
(0.1080)\end{array}$ & $\begin{array}{c}0.1638 \\
(0.1080)\end{array}$ \\
\hline $\ln$ (Geographic Area) & & $\begin{array}{c}0.0229 \\
(0.0170)\end{array}$ & \\
\hline $\ln$ (Population Density) & & & $\begin{array}{l}-0.0229 \\
(0.0170)\end{array}$ \\
\hline $\ln ($ Median Age $)$ & & $\begin{array}{c}0.7580 * * * \\
(0.2092)\end{array}$ & $\begin{array}{c}0.7580 * * * \\
(0.2092)\end{array}$ \\
\hline $\ln ($ Percent White $)$ & & $\begin{array}{c}0.0371 \\
(0.0850)\end{array}$ & $\begin{array}{c}0.0371 \\
(0.0850)\end{array}$ \\
\hline Constant & $\begin{array}{c}0.5996^{* * * *} \\
(0.3308)\end{array}$ & $\begin{array}{c}-4.0075^{* * *} \\
(1.2577)\end{array}$ & $\begin{array}{c}-4.0075^{* * *} \\
(1.2577)\end{array}$ \\
\hline$\gamma($ congestion parameter $)$ & 0.0923 & 0.0755 & 0.1022 \\
\hline Pseudo-R-squared & 0.0166 & 0.0219 & 0.0219 \\
\hline Chi^2 (H0: $\beta 2-\beta 3=-1)$ & $115.36^{* * * *}$ & $91.31 * * *$ & $110.02 * * *$ \\
\hline
\end{tabular}

${ }^{15}$ Table 2.4 estimates a demand function of DNA tests using the unit count as a measure of output. Elasticities are listed in this table, with the congestion parameter being calculated as the population elasticity divided by 1 plus the tax price elasticity. Statistical significance of $10 \%, 5 \%$, and $1 \%$ are represented by $*, * *$, and $* * *$ respectively.

Robust standard errors are in parenthesis. The results in this table suggest that DNA analysis contains a low degree of congestion, implying a club good and not a private good. 
Table 2.5: 2010 Poisson Cross Section Estimate of Unit Level DNA Case Output ${ }^{16}$

\begin{tabular}{|c|c|c|c|}
\hline & [10] & [11] & [12] \\
\hline Independent Variable & & & \\
\hline $\ln ($ Tax Price $)$ & $\begin{array}{l}-0.0872 \\
(0.0813)\end{array}$ & $\begin{array}{c}-0.1295^{* * *} \\
(0.0494)\end{array}$ & $\begin{array}{c}-0.1295^{* * *} * \\
(0.0494)\end{array}$ \\
\hline $\ln$ (Population) & $\begin{array}{c}0.1226 * * * \\
(0.0284)\end{array}$ & $\begin{array}{c}0.0935 * * * \\
(0.0187)\end{array}$ & $\begin{array}{c}0.1436 * * * \\
(0.0135)\end{array}$ \\
\hline $\ln$ (Disposable Income) & & $\begin{array}{c}0.3628 * * * \\
(0.0712)\end{array}$ & $\begin{array}{c}0.3628 * * * \\
(0.0712)\end{array}$ \\
\hline $\ln ($ Geographic Area) & & $\begin{array}{c}0.0501 * * * \\
(0.0143)\end{array}$ & \\
\hline $\ln$ (Population Density) & & & $\begin{array}{c}-0.0501 * * * \\
(0.0143)\end{array}$ \\
\hline $\ln ($ Median Age $)$ & & $\begin{array}{c}1.2025 * * * \\
(0.3355)\end{array}$ & $\begin{array}{c}1.2025^{* * * *} \\
(0.3355)\end{array}$ \\
\hline $\ln ($ Percent White $)$ & & $\begin{array}{c}0.1004 \\
(0.0884)\end{array}$ & $\begin{array}{c}0.1004 \\
(0.0884)\end{array}$ \\
\hline Constant & $\begin{array}{l}-0.1392 \\
(0.4471) \\
\end{array}$ & $\begin{array}{c}-8.6295^{* * *} \\
(1.2670)\end{array}$ & $\begin{array}{c}-8.6295^{* * * *} \\
(1.2670)\end{array}$ \\
\hline$\gamma($ congestion parameter) & 0.1344 & 0.1074 & 0.1649 \\
\hline Pseudo-R-squared & 0.0252 & 0.0378 & 0.0378 \\
\hline $\mathrm{Chi}^{\wedge} 2(\mathrm{H} 0: \beta 2-\beta 3=-1)$ & $107.24 * * *$ & $218.00 * * *$ & $176.71 * * *$ \\
\hline
\end{tabular}

${ }^{16}$ Table 2.5 estimates a demand function of DNA cases using the unit count as a measure of output. Elasticities are listed in this table, with the congestion parameter being calculated as the population elasticity divided by 1 plus the tax price elasticity. Statistical significance of $10 \%, 5 \%$, and $1 \%$ are represented by $*, * *$, and $* * *$ respectively. Robust standard errors are in parenthesis. The results in this table suggest that DNA analysis contains a low degree of congestion, implying a club good and not a private good. 
Table 2.6: 2010 Poisson Cross Section Estimate of Unit Level DNA Sample Output ${ }^{17}$

\begin{tabular}{|c|c|c|c|}
\hline & [13] & [14] & [15] \\
\hline \multicolumn{4}{|l|}{ Independent Variable } \\
\hline $\ln ($ Tax Price $)$ & $\begin{array}{l}-0.1591 * \\
(0.0900)\end{array}$ & $\begin{array}{c}-0.2217 * * * \\
(0.0584)\end{array}$ & $\begin{array}{c}-0.2217 * * * * \\
(0.0584)\end{array}$ \\
\hline $\ln$ (Population) & $\begin{array}{c}0.0981 * * * \\
(0.0274)\end{array}$ & $\begin{array}{c}0.0753 * * * \\
(0.0185)\end{array}$ & $\begin{array}{c}0.1147 * * * \\
(0.0165)\end{array}$ \\
\hline $\ln ($ Disposable Income $)$ & & $\begin{array}{c}0.3613 * * * \\
(0.0910)\end{array}$ & $\begin{array}{c}0.3613 \text { *** } \\
(0.0910)\end{array}$ \\
\hline $\ln ($ Geographic Area) & & $\begin{array}{c}0.0394 * * \\
(0.0159)\end{array}$ & \\
\hline $\ln$ (Population Density) & & & $\begin{array}{c}-0.0394 * * \\
(0.0159)\end{array}$ \\
\hline $\ln ($ Median Age) & & $\begin{array}{c}1.2752 * * * \\
(0.3208)\end{array}$ & $\begin{array}{c}1.2752 * * * \\
(0.3208)\end{array}$ \\
\hline $\ln ($ Percent White $)$ & & $\begin{array}{c}0.1984 * * \\
(0.0901)\end{array}$ & $\begin{array}{c}0.1984 * * \\
(0.0901)\end{array}$ \\
\hline Constant & $\begin{array}{r}0.1905 \\
(0.4639) \\
\end{array}$ & $\begin{array}{c}-8.5760 * * * \\
(1.4091) \\
\end{array}$ & $\begin{array}{c}-8.5760 * * * * \\
(1.4091) \\
\end{array}$ \\
\hline$\gamma($ congestion parameter) & 0.1167 & 0.0967 & 0.1473 \\
\hline Pseudo-R-squared & 0.0234 & 0.0406 & 0.0406 \\
\hline $\mathrm{Chi}^{\wedge} 2(\mathrm{H} 0: \beta 2-\beta 3=-1)$ & $74.18^{* * * *}$ & $134.38 * * *$ & $120.41 * * *$ \\
\hline
\end{tabular}

${ }^{17}$ Table 2.6 estimates a demand function of DNA samples using the unit count as a measure of output. Elasticities are listed in this table, with the congestion parameter being calculated as the population elasticity divided by 1 plus the tax price elasticity. Statistical significance of $10 \%, 5 \%$, and $1 \%$ are represented by $*, * *$, and $* * *$ respectively. Robust standard errors are in parenthesis. The results in this table suggest that DNA analysis contains a low degree of congestion, implying a club good and not a private good. 


\section{Chapter 3:}

\section{The Limits of Constraining Leviathan}

\subsection{Introduction}

Public choice economists commonly point to jurisdictional fragmentation, or sub-national government competition, as a way to constrain the Leviathan of government sector bureaucracy. If voters can "vote with their feet" an increase in the number and heterogeneity of sub-national governments ought to result in greater competition in both quality and cost, ceteris paribus, as jurisdictions endeavor to attract voters and thus taxpayers (Tiebout 1956). Interjurisdictional competition consequently places informal constraints on bureaucracy and government size by fostering incentives which align with voter preferences. As Niskanen (1971) explains, if this competition is lacking, and thus the financial incentive to pursue the goal of efficiency is missing, governments will pursue the goal of budget maximization or politician utility maximization instead. The result would be monolithic growth in government described by the Leviathan model in Brennan and Buchanan (1980).

The empirical literature which describes both the determinants of public sector size and government size's effect on the welfare of a population is mixed. This paper's purpose is to shed light on why the literature is mixed by exploring the long run and short run cost efficiency of a particular good at a national and sub-national level. Evidence in this paper suggests that provision of output by national systems which have a greater ability to tax rather than subnational governments does not affect efficiency or spending. Therefore, the bureaucratic effects from Leviathan behavior may not be a general explanation for public sector size.

The Leviathan model hypothesizes that only constitutional constraints on the size of government revenues and expenditures can control government. Campbell (1994), in a study 
which examines New Hampshire's constitution, shows that constitutional constraints that limit a state's ability to tax results in relatively lower government expenditure. The positive net migration into New Hampshire in the time period Campbell considers suggests that decreased government expenditure is welfare increasing. Nelson (1986), in a cross section study of the 50 U.S. states, also finds that constitutional limitations on a state's ability to tax tend to result in a relatively smaller public sector, and furthermore that the size of a state's public sector is negatively related to the number of local government units within that state. Constitutional constraints then, if positively related to the strength of a state's federalist structure, may also reduce government size indirectly by encouraging the development of local government competition.

Sjoquist (1982), Mehay (1984), Schneider (1986), and Marlow (1988), similar to Nelson (1986), find a negative relationship between the relative number of local governments units and public sector size. They suggest that an increase in the degree of local government fragmentation increases competition between governments and reduces government expenditures. An inverse relationship between federalism and the growth of government expenditure is also suggested by Schneider (1986). Mehay (1984) recognizes that local governments may not be able to fully take advantage of cost reductions which come from economies of scale, but suggests that the effect of decreased competition through centralization can overwhelm the cost benefits of increased size. The cross national studies by Cameron (1978), Saunders (1985), and Mueller and Stratmann (2003) agree, and also find an inverse relationship between sub-national government competition and government size.

Deacon (1979) and Mehay and Gonzalez (1985) demonstrate that there are several frameworks within which local government goods can be provided in a federalist structure. 
Deacon (1979) shows that municipalities can contract services out to private vendors who may be more able to operate at lower cost due to the absence of political border constraints. In the absence of political borders, private companies are not limited to provide goods to a set number of individuals and can grow or shrink dynamically across borders in order to operate at an efficient size. Empirically, Deacon finds cities which purchase services rather than provide them internally spend relatively less. Mehay and Gonzales (1985) also explore contracting out services, but to other local governments rather than private enterprises. They find that counties which supply public services to the cities and towns within their borders are able to provide services at lower cost due to economies of scale. Although counties which provide services for governments within their borders are often operating as a monopoly, they still face competition through the threat of entry by the cities within their borders.

In contrast to much of the public choice literature, Oates (1985) and Feld, Kirchgassner, and Schaltegger (2010) find no relationship between government fragmentation and expenditure size. Furthermore, Zax (1989) and Martinez-Vazquez and Yao (2009) find a positive relationship between the number of local governments and public sector size. Whether or not a larger or smaller public sector is welfare optimizing for society is also in question. Prud'homme (1995) and Nelson and Foster (1999) show that federalism may cause increases in corruption and decreases in personal income respectively. Stansel (2005) alternatively suggests that federalism is positively related to economic growth.

It is clear from the literature that the benefits of sub-national government competition and the benefits of economies of scale can be at odds with one another when deciding at what level of government public goods ought to be provided. Disagreements by scholars of federalism's effect on government expenditure results from how this tradeoff is balanced. Some data sources 
may show evidence of economies of scale dominating the balance over government competition, and other sources may show the opposite. In a market setting, this tradeoff does not exist since businesses compete to lower costs by operating at an efficient output size, and will create markets which cross political boarders. Government units however do not often have this ability, thus federalism's effect on government expenditure may then depend entirely on which force is stronger, which also depends upon which good is being provided.

As Ostrom, Tiebout, and Warren (1961) explain, the balance between economies of scale and federalism is complicated by the fact that perfect economies of scale are reached at different output levels for different goods, and one specific sized government cannot generally be an appropriate size for all government services. One service may be efficiently provided at a city level, whereas another service might be efficiently provided at a state or regional level. This efficiency is further affected by the characteristics of given cities, states, and regions in question, and changes dynamically. In a sense then, governments need to be able to transcend their borders in a fluid way in order to efficiently serve the needs of a population. This is apparent in the development of special purpose governments such as school districts.

Following from the ideas laid forth in Ostrom, Tiebout, and Warren (1961), this paper focuses on one service, being criminal DNA analysis, in order to provide evidence on whether federalism, centralism, or something in between is an appropriate framework for its provision specifically. By focusing on one good, the tradeoffs between jurisdictional fragmentations and economies of scale are more easily determined compared to an aggregated approach which ignores the efficiency differences between goods. This paper finds evidence that centralized national forensic laboratories are not more or less cost efficient in providing criminal DNA analysis. Centralization in the provision of forensic science may not then contribute to a 
Leviathan bureaucracy, and in fact could reduce government spending. This paper also finds little support that either national or sub-national government laboratories are generally efficient, and generally either have excess capacity or are overburdened given their fixed costs.

\subsection{Fiscal Federalism and the Provision of Local Public Goods}

The theory of fiscal federalism poses two main questions regarding the provision of a government provided good, the answers to which affect efficiency of production and thus the welfare of consumer-voters (Oates 1972). The first question the literature asks is what level of government ought to provide a given quantity of output, and the second question is what is the optimal quantity of output to be provided. Reflecting on these two questions separately provides valuable insight into the problem of determining the optimal federalist framework used to provide forensic science services. The problem of optimizing either a service area's size or output however leads to an important tradeoff. Ceteris paribus, consumers prefer goods to be provided by local governments rather than federal governments, yet local governments often cannot take advantage of the cost savings which come from larger output levels and economies of scale.

\subsubsection{What Level of Government Ought to Provide a Given Quantity of Output?}

The reason consumers tend to prefer local government output over national output is that when service areas are small, local government output can be more easily customized to the preferences of the individuals of a community (Oates 1997). It is also likely that the ability of consumers to hold government officials accountable increases as the size of government decreases, since it is easier for an individual to voice their opinion at a town hall meeting than to get their voice heard on a national stage. As an illustration consider Figure 3.1 developed by Oates (1997), and adapted to look specifically at forensic science services. In this model, it is 
assumed there are two service areas or jurisdictions in need of forensic science services labeled 1 and 2, and one central government. It is also assumed that the price of a unit of forensic science services is positive and equals the marginal cost (MC) per resident per unit of forensic science output f. Assuming MC is positive implies that this government provided good is not a purely public good and experiences congestion in consumption as suggested by McAndrew (2012a) ${ }^{18}$. As one can see the optimal level of output of $\mathrm{f}$ for jurisdiction 1 occurs where $D_{1}$ intersects MC at point $A$ and an output level of $f_{1}$, and the optimal level of output of $f$ for jurisdiction 2 occurs where $D_{2}$ intersects $\mathrm{MC}$ at point $\mathrm{E}$ and an output level of $\mathrm{f}_{2}$. Suppose however that rather than having jurisdictions 1 and 2 individually provide their preferred level of forensic science output, a central government provides this service at a uniform level of $\mathrm{f}_{0}$ for both districts. It is clear that at a level of output of $\mathrm{f}_{0}$ economic surplus is no longer maximized and there is a loss in social welfare, with area $\mathrm{ABC}$ being the deadweight loss for jurisdiction 1 and area DCE being the deadweight loss for jurisdiction 2. This simple example illustrates that when the preferences for forensic science output are strong and diverse it may be preferable to provide output at a relatively small jurisdictional level. Fiscal decentralization is thus more important where strongly heterogeneous population groups exist.

If the preferences of individuals within service areas are heterogeneous, this example can be extended as jurisdictions 1 and 2 are split into ever smaller levels of jurisdictional sizes one will eventually reach a point where every jurisdiction consists of one individual i. The consumption of $\mathrm{f}_{\mathrm{i}}$ by each jurisdiction will behave as a private good and no longer be relevant in any significant sense if the goal is to analyze public output to groups. Additionally, most

\footnotetext{
${ }^{18}$ Since the marginal cost of providing the good to an additional resident in a jurisdiction is greater than zero, the good would not meet the definition of a public good where the marginal cost of providing a public good to an additional consumer is zero.
} 
individuals would find it cost prohibitive to individually provide any level of the government good $\mathrm{f}_{\mathrm{i}}$, and will thus need to form sharing arrangements. For example, one criminal DNA case can cost as much as $\$ 4,000$. One must then assume that either consumer-voters have relatively homogeneous preferences within given service areas, or that consumer-voters with dissimilar preferences will coordinate within a jurisdiction to reach an optimal collective sharing decision with multiple individuals deciding on what level of $f$ is to be produced and consumed. This will allow for a more realistic representation of the provision of forensic science services, and also will lead to the benefits of cost sharing described by Buchanan (1965) in his theory of clubs.

The optimal service area or club size for providing any good, including forensic science service output occurs, according to Buchanan (1965), at the point where the difference between the benefit and the cost of increasing the sharing arrangement is maximized. In Figure 3.2 the benefit curve represents the individual level benefit of forensic science services at different sizes of sharing arrangements, and the cost function represents the per person cost of providing these services at different levels of sharing as well. When there is only one individual, the cost of providing forensic science services would be exorbitantly high due to large fixed costs involved. The total expenses are so high that the cost to the individual is more than the benefit received and they will choose to not provide forensic science services as depicted at point $\mathrm{N}_{1}$ in Figure 3.2. As more individuals are added to the sharing arrangement then the cost per person to provide these forensic services will decline. The benefit function will also increase as access to previously unaffordable resources becomes available to all individuals in the club under a larger sharing arrangement. Setting up a forensic laboratory is costly, but as service areas grow or collaborate with neighboring service areas to create cross jurisdictional laboratories or laboratory 
systems, more and perhaps better technology can be afforded which will increase the benefits to all individuals.

Eventually however if this sharing arrangement continues to grow the benefit function will peak and then decrease as congestion sets in, where further sharing no longer adds a benefit to individuals in the group. Congestion can happen when a growing service area arrangement becomes too large causing bureaucratic inefficiencies. Alternatively, congestion occurs if individuals, now with a smaller influence on the group, no longer consume close to their preferences when the group as a whole has decided upon some level, type, or quality of consumption which is undesirable to the individual. This situation is depicted at point $\mathrm{N}_{2}$ in Figure 3.2 where the benefits are decreasing and the costs increasing.

Consider the simple example given in Maguire et al. (2012) in which a small county laboratory has a high average total cost in DNA testing due to large fixed costs and low levels of submissions. The county may consider outsourcing their DNA casework to a larger state run laboratory in order to take advantage of the state's economies of scale. The dollar cost per individual in the county for DNA casework may fall as a result of the sharing arrangement with the state laboratory. However the county's influence on the laboratory performing this work will also decrease. If state level DNA casework submissions are proffered a priority over county level submissions, the benefits of average cost reduction for the county may be smaller than the increased cost of undesirable queuing and the corresponding increased wait time that results. In this case the sharing arrangement for individuals in the small county should be smaller than the state level laboratory system.

The point $\mathrm{N}^{*}$ in Figure 3.2 represents the optimal club or sharing arrangement size where the difference between the benefit function and cost function is maximized. Exactly where $\mathrm{N}^{*}$ is 
located in reality will determine the optimal service area size to provide forensic services; that is, whether these services ought to be provided at the local, state, or national level or provided by some other options including outsourcing services, insourcing, or even privatizing if these options are better able to operate near the optimum, $\mathrm{N}^{*}$.

\subsubsection{What is the Optimal Quantity of Output to be Provided?}

The second question from the theory of fiscal federalism seeks to determine the optimal level of output of a good, and is parallel to determining the optimal club or service area size. Finding the optimal level of forensic output is empirically more practical than determining the optimal service area size due to the type of data that is available, such as that found in project FORESIGHT (Houck et al. 2009). The benefit and cost to individuals from larger or smaller sharing arrangements is inherently difficult to measure when preferences are subjective and not easily comparable. Output levels and their costs conversely are objective measures which forensic laboratories can record explicitly as numbers.

By using output data, an average total cost function can be estimated which would help laboratory directors determine whether bigger is better, or whether more or less output lowers average total cost. An average total cost function can also be specified to account for efficiency differences in local and state versus national laboratories. If a forensic laboratory which initially operated at a low level of output began to produce more, perhaps by insourcing from bordering jurisdictions, it would begin to experience economies of scale, or a decrease in average total cost. Reasons for this could come from increased use of idle laboratory resources, better management, or labor specialization as forensic scientists perform more specific tasks to improve efficiency given a larger output level. Bigger will not always be better however, and eventually as output continues to increase diseconomies of scale, or an increase in average total cost will result. This 
can occur as bureaucratic inefficiencies result from the growing complexity of managing larger output levels, or from the congestion of limited laboratory resources.

Operating at the minimum point on the long run average total cost function, thus achieving perfect economies of scale, is the most cost efficient point of operation. Although government operated laboratories can operate at this point, it would likely be coincidental. If sharing arrangements are largely determined by political borders rather than economic efficiency and competition, one would expect a government output level that is either too large or too small (Poole 1983; Benson 1998; McAndrew 2012b). The private sector is not limited by the size of any jurisdiction and therefore its output is not related to a politically created sharing arrangement or border. Contracting out services by governments to the private sector has therefore been unsurprising. One important way the private sector can compete is through cost reduction by operating at the minimum point on the average total cost function, as any deviation to the left or right would decrease their competitiveness. Alternatively, by empirically estimating the optimal output size of a good, special purpose governments which transcend current political borders could be developed for the forensic science industry which forestall or substitute for privatization.

This paper explores whether forensic laboratories in the Unites States operating under a mostly federalist structure are more or less efficient than their international counterparts which are centralized at a national level. The United States has a myriad list of organizational frameworks to provide forensic services (Houck \& Siegel 2010) which likely developed due to historical circumstance, political constraints, and the large population and geographic size of the country. The previously described example developed by Maguire et al. (2012) illustrates this well. Often political units at a local level will purposefully operate at higher cost in the short run 
and not take advantage of economies of scale in order to maintain independence and control of their laboratory system for reasons that are not directly financial.

This is shown in Figure 3.3, which depicts three short run average cost curves and their envelope function which is the long run average cost curve. Consider SRATC2, which assumes a given level of fixed costs. It is often the case that laboratories are overwhelmed with work, represented by point $\mathrm{C}$. At this point a laboratory does not have enough resources to be cost efficient and could improve by increasing their level of fixed cost to that represented by SRATC3. Alternatively, laboratories can experience excess capacity and idle resources which decreases cost efficiency, represented by point A. In this case downsizing to decrease fixed costs could also make a laboratory more efficient in the short run, as depicted by SRATC1. In both these situations shown by point $\mathrm{A}$ and $\mathrm{C}$ there is inefficiency in the short run and long run.

International laboratories however are often nationally consolidated and consequently do not face the political constraints that occur at the sub-national level. For example, the only provider of forensic services in New Zealand is Environmental Science and Research Limited (ESR). Due to the relatively smaller geographic and population size of New Zealand, and a lack of competing forensic laboratories in the country, ESR is able to operate at a point which, given the size of the country, is efficient. Point B in Figure 3.3 depicts this situation. Point B is efficient in the short run, but it is not cost minimizing in the long run. A movement towards increased output however is likely not a pragmatic solution for this island nation. Indeed, the political constraints at the national level for some smaller countries may be such that further increases in output would be impractical. 


\subsection{Data and Empirical Model}

The efficient level of forensic science output, and the relationship between cost and size in this industry, is determined by estimating a cost function. Within this cost function, the effects of institutional differences between domestically operated local laboratories and internationally operated federal laboratories are also analyzed. The empirical model used in this paper follows a similar framework as Knapp (1982) who estimates the economies of scale in British crematoria, and who found a cost function which is indeed quadratic in output, tracing out a statistically significant U-shape. It is assumed that output in forensic science laboratories is exogenously determined through crime, and any other factors which affect cost are also assumed to be exogenous. Ordinary least squares estimation should therefore be an appropriate method for estimating the parameters which determine the average cost of a forensic laboratory. ${ }^{19}$ The functional form of this empirical model is as follows:

$$
\begin{aligned}
& \text { ATC }_{j}=\beta_{1}+\beta_{2} \text { output }_{j}^{2}+\beta_{3} \text { output }_{j}+\beta_{4} \text { national }_{j} \\
& \left.\quad+\beta_{5}\left(\text { national }_{j} * \text { output }_{j}\right)+\beta_{6} \text { (national }_{j} * \text { output }_{j}^{2}\right) \\
& \quad+\beta_{7} z_{j}+\varepsilon_{j}
\end{aligned}
$$

where $A T C_{j}$ is the average cost of a criminal DNA case for a laboratory providing output to service area $j, o u t p u t_{j}^{2}+$ output $_{j}$ is a laboratory's output squared plus output which captures the nonlinearity of an average total cost function within a linear estimation technique, national $_{j}$ is a dummy variable where 1 represents a nationally operated laboratory outside of the U.S. and 0 represents a state or local laboratory, national $_{j} *$ output $_{j}$ and national $_{j} * o u t p u t_{j}^{2}$ are

\footnotetext{
${ }^{19}$ The nonparametric method of data envelopment analysis is an alternative approach which will be used in future research.
} 
product dummy variables which allows for changes in the slope coefficient of national as output changes, $z_{j}$ is a vector of laboratory characteristics, and $\varepsilon_{j}$ is the error term.

The dummy variable national ${ }_{j}$ is included to capture the effects of centralization, where a positive coefficient would imply that centralization leads to increased long run average cost.. The product dummy variable is included since the effect of national on $A T C_{j}$ is not necessarily constant, and could change as output changes. A positive coefficient on the product dummy would imply an increasing slope for national as output ${ }_{j}$ rises. This could occur if small countries behave similar to a state or local government rather than a federal government.

Product quality is also a desired variable to include in empirical studies which estimate the average cost of a good. For this study however it is assumed product quality is constant in the sample set, since laboratories used in this paper all produce under rigid ISO/IEC 17025 laboratory certification guideline ${ }^{20}$ and there is no reason to believe that quality differences are large or nonrandom. Furthermore, in studies which do contain data on product quality, as in Christofferson et al. (2007), the data only goes so far as categorical dummy variables in which quality could vary substantially within each category.

Equation (3.1) is estimated using data from the National Institute of Justice's project FORESIGHT, which is a newly developed system for evaluating the business metrics of forensic laboratories domestically and internationally (Houck et al. 2009). The data used in this study is a cross section of year 2010. Although alternative datasets containing information on the forensic science industry are available, such as the Census of Publicly Funded Forensic Crime Labs or the International Association for Identification: Forensic Service Providers Survey, FORESIGHT

\footnotetext{
${ }^{20}$ According to standards.org, "ISO/IEC 17025 is the global recognized standard that was developed specifically for testing and calibration laboratories that intended seeking accreditation. It is also the basis for accreditation from an accreditation body. The current release was published in 2005. It covers testing and calibration performed using standard methods, non-standard methods, and laboratory-developed methods."
} 
improves upon them by the standardization of business metric definitions across laboratories, and the inclusion of private and international laboratory data. Output is measured by the number of criminal DNA cases completed, thus average cost will be measured by the average cost of a criminal DNA case. Descriptive statistics are shown in Table 3.1. As one can see, average costs and output vary greatly. Data on the number of tests per case and several salary measures are also included, which form the vector $z_{j}$ which represents laboratory characteristics.

\subsection{Results}

Table 3.2 displays the results from estimating equation (3.1) using FORESIGHT data. In every specification, the coefficient on output $t_{j}$ is negative and statistically significant and the coefficient on output ${ }_{j}^{2}$ is positive and statistically significant. This implies that average total cost and output are related in the expected quadratic fashion, with perfect economies of scale estimated to occur between 5,732 and 8,830 criminal DNA cases. Long run cost inefficiencies therefore result from laboratories producing either less than 5,732 or more than 8,944 criminal DNA cases. The national $_{j}$ dummy variable in specifications [2] through [5] does have a negative coefficient, implying that the centrally operated international laboratories have lower costs, however this relationship is not statistically significant. Similarly, the national $_{j} *$ output $_{j}$ and national $_{j} *$ output $_{j}^{2}$ product dummy variables in specification [3] and [5] were not statistically significant, implying that the slope on national $_{j}$ does not change as output ${ }_{j}$ changes. In other words, whether a laboratory is nationally or locally operated does not have an effect on cost in the long run. In specifications [4] and [5] the effects of the vector $z_{j}$ are estimated. Intuitively, the number of cases per forensic analyst is negatively related to average cost. If analysts are more productive in processing cases, average costs ought to decline. 
Support salary and operations salary is also positively related to average cost, implying that as salaries rise, so to do costs.

This estimate of an average total cost function presented in Table 3.2 provides only the long run estimate of average total cost. Many jurisdictions however do not have the resources or political ability to move quickly to a long run efficient point. In the short run then it should also be the goal of cost minded laboratories to be efficient, given their size and fixed costs. A short run efficient point of operation occurs on the lowest point of the short run average total cost function which is tangent to the long run average total cost function, previously depicted as point B in Figure 3.3.

Many sub-national U.S. laboratories are not efficient even in the short run, and do not operate near the estimated long run cost curve as shown in the scatter plot in Figure 3.4. International forensic laboratories which operate at a consolidated national level, likely due to a smaller degree of political border constraints and less strict regulations regarding the outsourcing or insourcing evidence for processing, may however be able to operate more efficiently in the short run. The scatter plot in Figure 3.4 however shows that this is not the case. Counter to expectations, nationally operated laboratories are not more or less efficient in the short run compared to sub-nationally operated laboratories. There is no statistical evidence for an intuitional cost benefit from running a laboratory at the federal versus local level. The main driver behind cost efficiency lies elsewhere.

\subsection{Conclusion and Policy Recommendation}

The Leviathan model described by Brennan and Buchanan (1980) proposes that constitutional constraints on a government's ability to tax are necessary to prevent excessive growth in public spending. The public choice literature largely supports this, and finds that the 
power to tax along with other bureaucratic forces in federal governments leads to public sector growth. This paper in contrast, provides evidence that strong national governments can provide criminal DNA analysis at a similar level of efficiency compared to sub-national governments. Government spending is not necessarily increased, ceteris paribus, if national laboratories provide this service. The efficient estimated range of output for all laboratories is determined to be between 5,732 and 8,830 DNA cases processed.

It is clear that federalism's or centralism's effect on government spending is more complex than many previous studies have portrayed. The short run and long run are both important in determining policy, as there are often binding constraints due to historical circumstance that may not allow quick changes in fixed costs. The specific good considered also matters in determining policy, since economies of scale will change as the good considered changes. Indeed, it may be the case that special purpose governments ought to be developed which transcend political borders in order to take advantage of the economies of scale in regulated industries, much like public schooling has already done.

There are several policy actions which could improve the output of forensic science specifically. In the short run, laboratories operating at a point significantly higher than the estimated long run average total cost curve ought to work toward efficient operations within their preexisting laboratory system. As an example, consider how work shifts change at laboratories. Currently, many laboratories use shifts such that everyone clocks out at the end of a shift, and the new shift then comes in. This can lead to disruptions in analysis and work if the newly arriving shift needs to figure out what the previous shift has accomplished. Instead, laboratories ought to overlap shifts, where someone always knows where the laboratory is with the day's work. 
In the long run, laboratories also need to work towards moving to their most efficient point on the long run average total cost curve. One policy already discussed to achieve this is through the use of special purpose governments which transcend borders. Another policy would be to use correspondent laboratories, much like the banking system uses correspondent banks. By using correspondent laboratories, smaller laboratories can take advantage of the services, and economies of scale of a much larger operation. Bode Technology and Marshall University's forensic laboratory currently operate in this fashion and will accept and process external laboratories' work at a lower cost. A third policy to increase the long run efficiency of forensic laboratories is to diversify outside of the industry. The crime laboratory in Charleston, WV, for instance, processed water samples after the 2013 chemical spill into West Virginia's water supply. Much of the machinery and equipment to process environmental or public health samples is identical to forensic science equipment. By taking advantage of economies of scope, the industry may be able to lower costs in a way not yet seen in most government owned laboratories. 


\section{Figure 3.1: Centralized Versus Decentralized Output Decisions for Forensic Science Services $^{21}$}

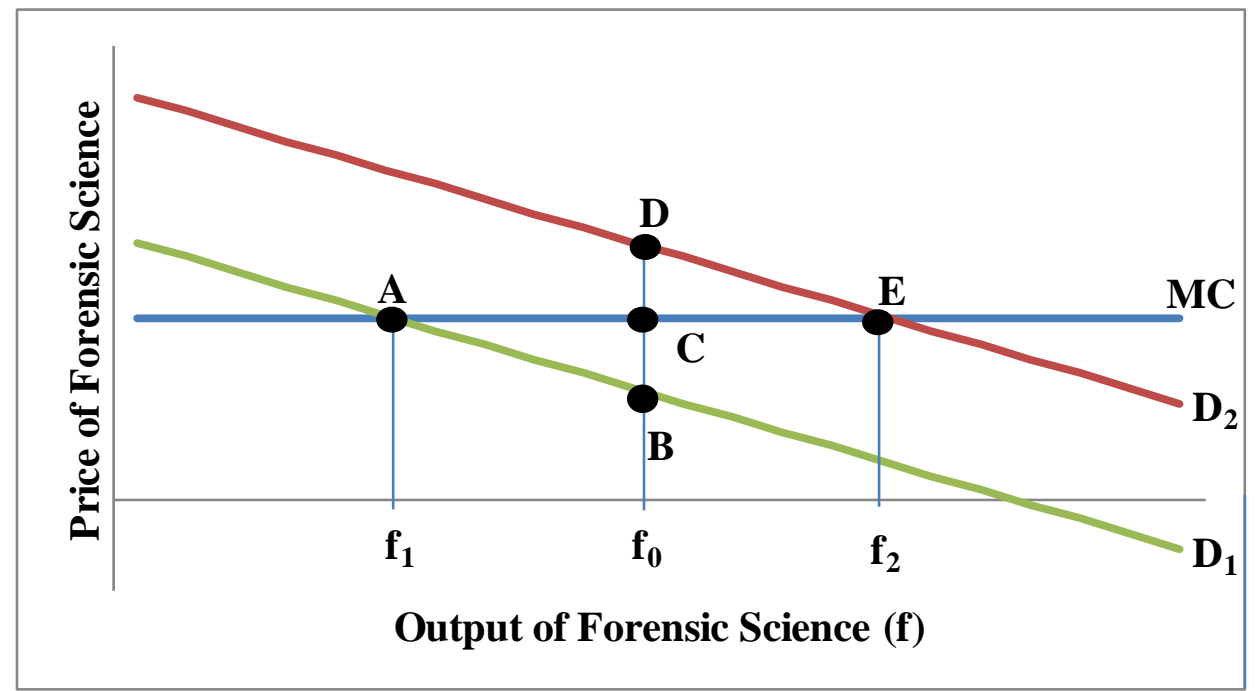

\footnotetext{
${ }^{21}$ Figure 3.1 illustrates demand curves $\mathrm{D}_{1}$ and $\mathrm{D}_{2}$ for jurisdictions 1 and 2, who prefer an output level of forensic science of $f_{1}$ and $f_{2}$ respectively. This preference is determined by the intersection of their individual demand curves with the marginal cost curve MC. If a national authority however imposed upon them a consumption level of $\mathrm{f}_{0}$, a deadweight lost of area $\mathrm{ABC}$ would be felt by jurisdiction 1, and a deadweight loss of area CDE would be felt by jurisdiction 2 since neither jurisdiction would then have their preferences met.
} 
Figure 3.2: The Optimal Forensic Science Service Area Size ${ }^{22}$

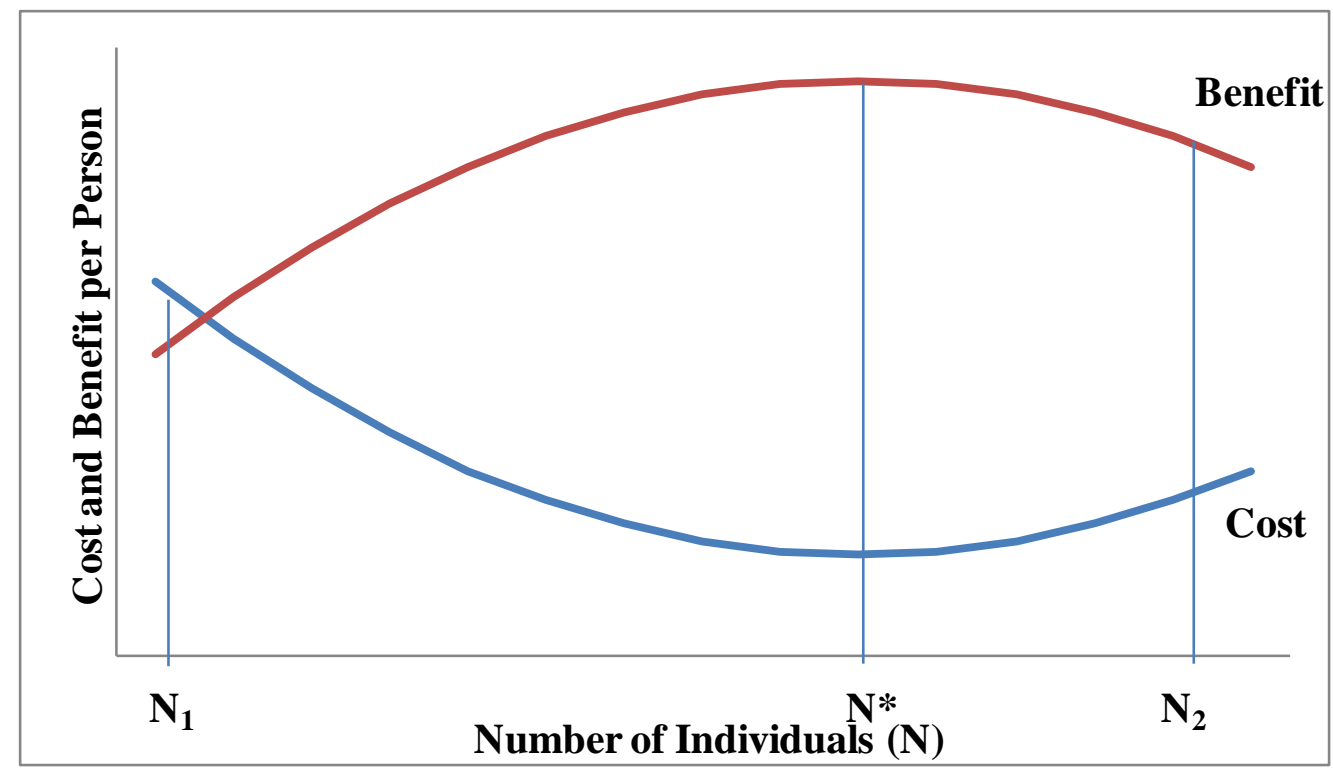

\footnotetext{
${ }^{22}$ The optimal jurisdiction size as measured by population, $\mathrm{N}$, served by a forensic laboratory is determined by the tradeoffs of individuals' costs and benefits. When there are relatively few people served by a laboratory, such as at level $\mathrm{N}_{1}$, the minimum fixed cost of equipment and personnel will be overly large relative to the benefit per person. As more individuals are added to the jurisdiction however, cost per person drops and benefits rises up to the optimal level $\mathrm{N}^{*}$ where the difference between individuals' benefit and cost is maximized. Further increases in population served past $\mathrm{N}^{*}$ will lead to congestion in consumption, with a decrease in benefits and an increase in costs per person such as at level $\mathrm{N}_{2}$.
} 
Figure 3.3: Short Run and Long Run Average Total Cost of Forensic Science Services ${ }^{23}$

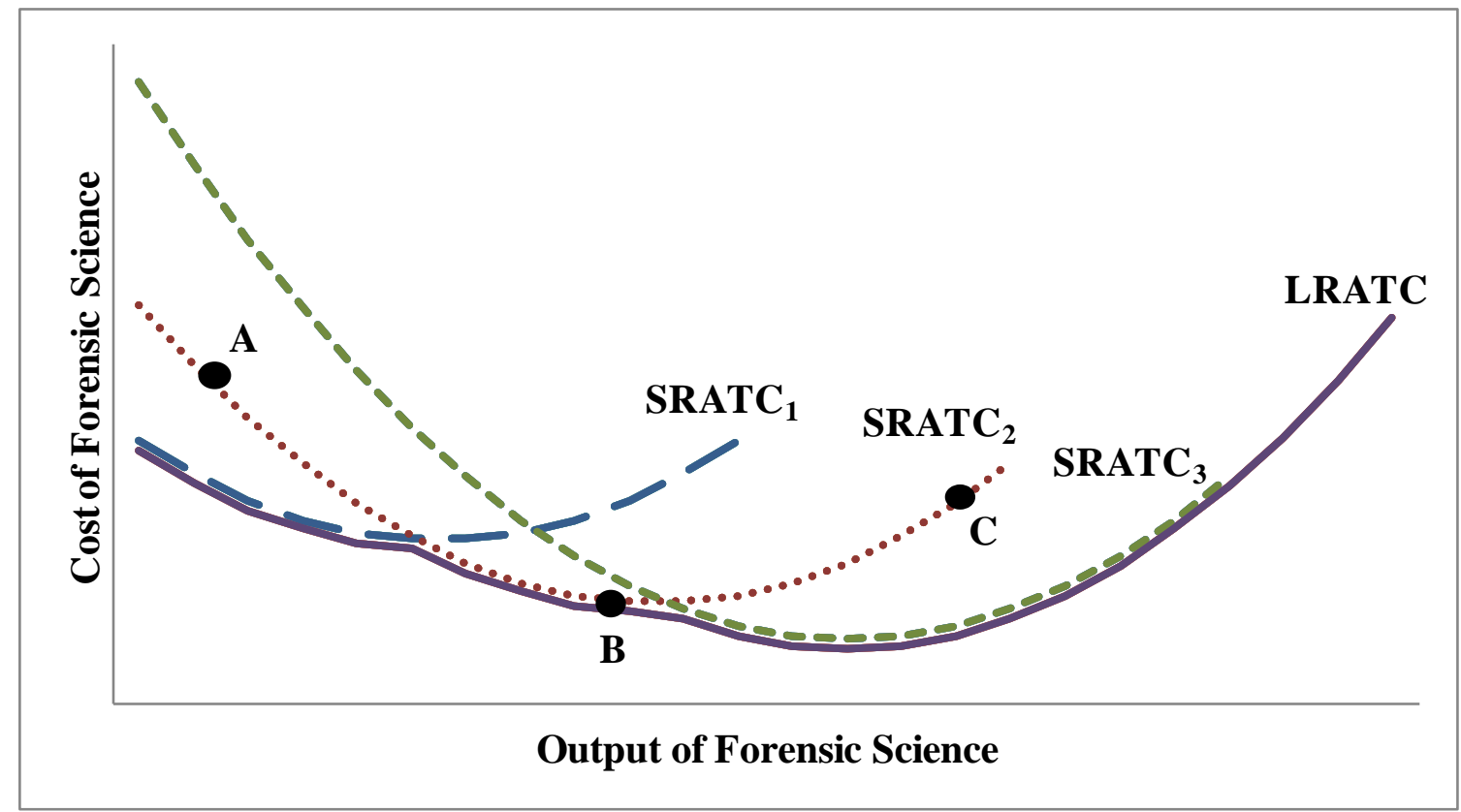

\footnotetext{
${ }^{23}$ Figure 3.3 shows three short run cost curves, $\mathrm{SRATC}_{1}, \mathrm{SRATC}_{2}$, and $\mathrm{SRATC}_{3}$, whose envelope function is a long run cost curve LRATC. Given the fixed costs associated with $\mathrm{SRATC}_{2}$, point A is inefficient due to idle resources, point $C$ is inefficient due to overcapacity, and point $C$ is efficient since it is the lowest point on $\mathrm{SRATC}_{2}$ which is tangent to LRATC. None of these points A, B, or $\mathrm{C}$ however are efficient in the long run which would occur at the lowest point(s) on LRATC.
} 
Figure 3.4: Long Run Average Cost of Criminal DNA Cases ${ }^{24}$

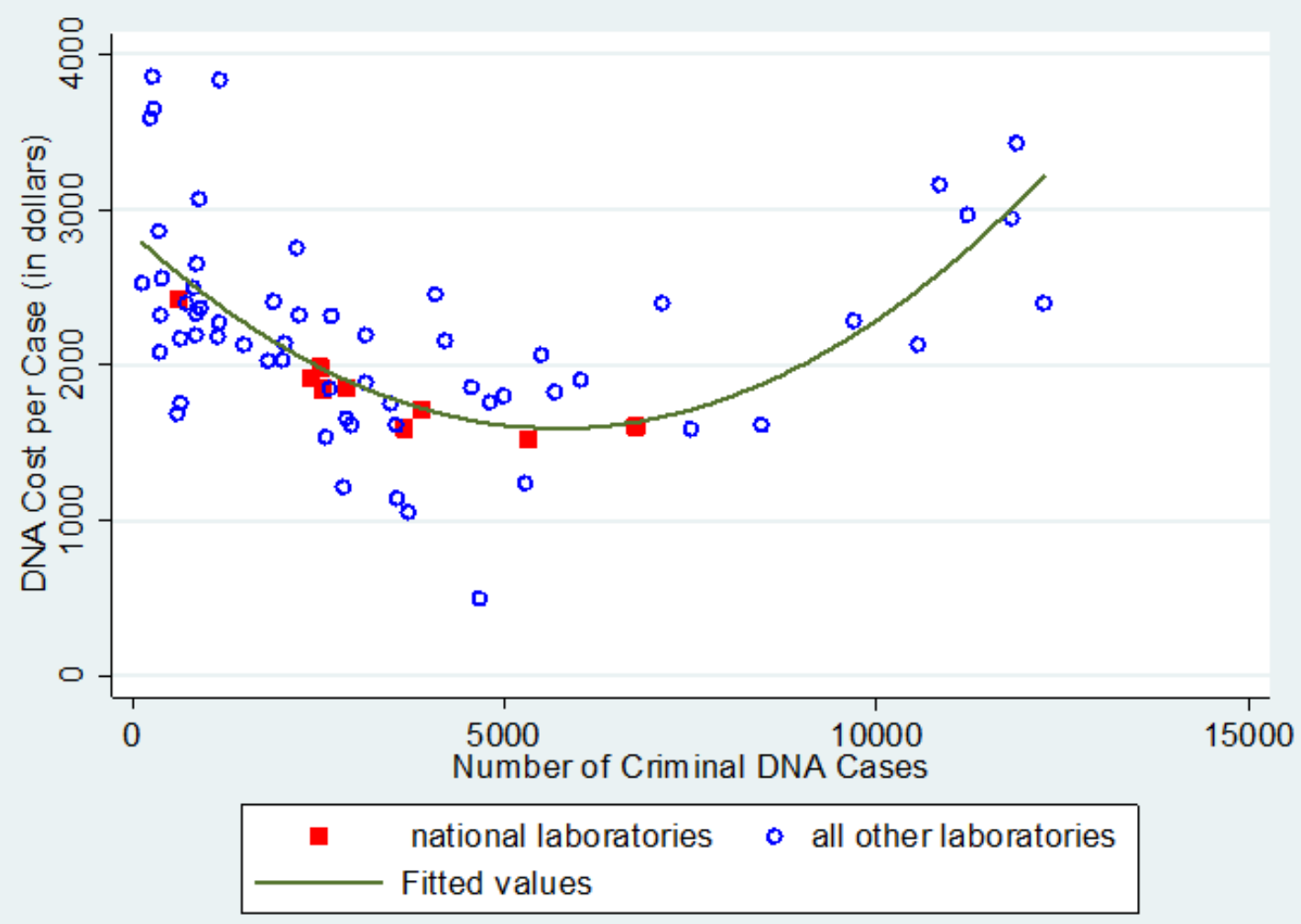

${ }^{24}$ Figure 3.4 shows the quadratic relationship between the output and average cost of criminal DNA cases recorded in the FORESIGHT dataset. This U-shaped relationship suggests that the theory of economies and diseconomies of scale is correct. This graph also suggests that national laboratories operate closer to the estimated long run cost curve and are thus more efficient in the short run. 
Table 3.1: Descriptive Statistics ${ }^{25}$

\begin{tabular}{crrrr}
\hline Variable & \multicolumn{1}{c}{ Mean } & Std. Dev. & \multicolumn{1}{c}{ Min } & Max \\
\hline DNA Cost per Case & $\$ 2,163.47$ & $\$ 643.27$ & $\$ 495.45$ & $\$ 3,853.85$ \\
Output of DNA Cases & $3,523.88$ & $3,246.16$ & 125.00 & $12,258.00$ \\
National Dummy & 0.19 & 0.39 & 0 & 1 \\
DNA Tests per Case & 11.70 & 3.71 & 0.64 & 25.94 \\
DNA Cases per Forensic Analyst & 52.87 & 51.62 & 32.05 & 424.18 \\
DNA Support Salary (total) & $\$ 244,567.80$ & $\$ 442,854.70$ & $\$ 6,104.61$ & $\$ 3,250,516.00$
\end{tabular}

${ }^{25}$ Table 3.1 describes a 2010-2011 National Institute of Justice FORESIGHT cross section dataset on criminal DNA cases. This dataset contains local and state laboratories from the U.S., and nationally operated laboratories outside the U.S. 
Table 3.2: OLS Estimate of the Long Run Average Cost of a Criminal DNA Case ${ }^{26}$

\begin{tabular}{|c|c|c|c|c|c|}
\hline & [1] & [2] & [3] & [4] & [5] \\
\hline Independent Variable & Coefficient Estimates & & & & \\
\hline Output & $\begin{array}{c}-0.4356 * * * \\
(0.0595)\end{array}$ & $\begin{array}{c}-0.4306 * * * \\
(0.0602)\end{array}$ & $\begin{array}{c}-0.4311 * * * \\
(0.0646)\end{array}$ & $\begin{array}{c}-0.4295 * * * \\
(0.0585)\end{array}$ & $\begin{array}{c}-0.4347 * * * \\
(0.0641)\end{array}$ \\
\hline Output`2 & $\begin{array}{l}3.8 \mathrm{e}-05 * * * \\
(5.07 \mathrm{e}-06)\end{array}$ & $\begin{array}{l}3.75 \mathrm{e}-05 * * * \\
(5.16 \mathrm{e}-06)\end{array}$ & $\begin{array}{l}3.76 \mathrm{e}-05 * * * \\
(5.47 \mathrm{e}-06)\end{array}$ & $\begin{array}{c}2.44 \mathrm{e}-05^{* * *} * \\
(6.19 \mathrm{e}-06)\end{array}$ & $\begin{array}{l}2.43 \mathrm{e}-05 * * * \\
(6.50 \mathrm{e}-06)\end{array}$ \\
\hline National & & $\begin{array}{c}-96.1769 \\
(177.0483)\end{array}$ & $\begin{array}{l}-176.2034 \\
(661.2943)\end{array}$ & $\begin{array}{l}-138.5144 \\
(128.9699)\end{array}$ & $\begin{array}{c}-95.8898 \\
(580.0132)\end{array}$ \\
\hline National*Output & & & $\begin{array}{c}0.0361 \\
(0.3730)\end{array}$ & & $\begin{array}{l}-0.0625 \\
(0.3284)\end{array}$ \\
\hline National* Output $^{2}$ & & & $\begin{array}{l}-2.87 e-06 \\
(4.67 e-05)\end{array}$ & & $\begin{array}{l}1.46 \mathrm{e}-05 \\
(4.14 \mathrm{e}-05)\end{array}$ \\
\hline Number of test per case & & & & $\begin{array}{c}22.7294 \\
(14.1771)\end{array}$ & $\begin{array}{c}21.0165 \\
(14.5528)\end{array}$ \\
\hline $\begin{array}{l}\text { Number of cases per forensic } \\
\text { analyst }\end{array}$ & & & & $\begin{array}{c}-2.6127 * * * \\
(1.1095)\end{array}$ & $\begin{array}{c}-2.5137 * * \\
(0.0001)\end{array}$ \\
\hline Support salary & & & & $\begin{array}{c}0.0002 * * \\
(0.0001)\end{array}$ & $\begin{array}{l}0.0002 * \\
(0.0001)\end{array}$ \\
\hline Operations salary & & & & $\begin{array}{l}0.0001 * * \\
(-0.0001)\end{array}$ & $\begin{array}{c}0.0001 * * \\
(5.90 \mathrm{e}-05)\end{array}$ \\
\hline Constant & $\begin{array}{c}2839.2170 * * * \\
(121.243) \\
\end{array}$ & $\begin{array}{c}2855.9230 * * * \\
(124.1838) \\
\end{array}$ & $\begin{array}{c}2.846 .2590 * * * \\
(127.8658) \\
\end{array}$ & $\begin{array}{c}2563.3840 * * * \\
(215.9777)\end{array}$ & $\begin{array}{c}2565.3780 * * * \\
(223.3561) \\
\end{array}$ \\
\hline R-squared & 0.4614 & 0.4653 & 0.4641 & 0.6133 & 0.6114 \\
\hline Adjusted R-squared & 0.4451 & 0.4406 & 0.4215 & 0.5681 & 0.5511 \\
\hline F-statistic & $28.27 * * *$ & $18.85 * * *$ & $10.91 * * *$ & $13.59 * * *$ & $10.14 * * *$ \\
\hline
\end{tabular}
26 Table 3.2 estimates a long run average total cost function for criminal DNA cases using FORESIGHT data. Statistical significance of $10 \%, 5 \%$, and $1 \%$ are
represented by $* * *$, and $* * *$ respectively. Standard errors are in parenthesis. 


\section{Chapter 4:}

\section{When Leviathans Fail to Maximize Revenue: A Theoretical Analysis of the Social Benefits of Leasing by Tax Exempt Entities}

\subsection{Introduction}

Three decades ago, Brennan and Buchanan (1980) overturned the traditional public finance tax literature by modeling governments as malevolent revenue maximizers, determined to extract as much money from taxpayers as possible. At the time, the more traditional model assumption of governments was a benevolent public good provider who seeks to raise a given amount of revenue to cover the cost of a predetermined level of public goods. Indeed, Brennan and Buchanan suggest that without constitutional limitations on governments' ability to tax, governments will become Leviathans who seek not to raise a given revenue but rather to maximize revenue to the extreme much like a virus growing in an organism. The policy implications from this assumption were disturbing to public finance economists at this time (Oates 1985; Musgrave 1981), yet Leviathan behavior in governments has become the common assumption for public choice economists to make. Stansel (2005), Mueller and Stratmann (2003), and Campbell (1994) among many other public choice scholars use a Leviathan assumption in modeling revenue accumulation of governments.

There has been a debate between public finance and public choice economists about the extent to which Leviathan behavior in governments exists, as well as whether this behavior is welfare maximizing, since the Leviathan model was developed. Yet, there is simply no a priori reason to believe that the goal or result of governments is to maximize the public sector. Feld, Kirchgassner, and Schaltegger (2010), Marinez-Vazquez and Yao (2009), Zax (1989), and Oates (1985) empirically find either no or conflicting evidence that restrictions on a government's ability to tax reduces government size. This suggests national governments with a greater power 
to tax may in fact lower public sector growth. For instance, national governments may have better cost efficiencies compared to municipalities or state governments, and thus benefit from economies of scale. Another reason could be the preferences of voters. Voters may be more likely to vote for increases in the provision of public goods at the local rather than national level since they may have more control on the quality and provision of the goods at the local level. A third and unexplored reason for the possible nonexistence of Leviathan behavior, which is the focus of this paper, is ineffective national policy. It may be that national governments are simply ineffective in maximizing revenue and/or have goals counter to revenue maximization.

Consider the 1981 Economic Recovery and Tax Act (ERTA) and subsequent 1984 Deficit Reduction Act (DEFRA) which were signed into law by President Ronald Reagan for the purpose of encouraging economic growth and to close tax loopholes in order to raise net tax revenue. Although ERTA incentivizes capital growth by changing the tax laws for the expensing of depreciable property of private entities, DEFRA discourages capital growth for tax exempt entities. One provision within DEFRA attempted to increase federal tax revenues by reducing tax benefits for property leased by tax exempt entities. Before DEFRA, tax exempt entities could increase their effective budgets by leasing rather than purchasing capital assets. Private leasing companies benefit from the deductibility of depreciation from their taxable income. Since tax exempt entities do not pay taxes, they can benefit by leasing capital from the private sector at a lower cost rather than making purchases themselves. The direct effect of leasing by tax exempt entities is a lowering of federal tax revenues since the federal government will receive lower tax payments as a result of deprecation tax benefits (Blose and Martin 1989; Masse, Hanrahan, and Kushner 1988; Callahan 1981). 
Before 1984, the federal government was in effect subsidizing the budgets of municipalities, states, and other federal agencies such as the Navy through the tax system with no direct control over these subsidies, which at the time were not looked upon favorably by Congress or the president. DEFRA was thus passed in part to disallow sub-national governments and other federal agencies from manipulating the portion of their budgets which come from the federal government. The opinion of Congress is made known by reading the comments from the Joint Committee on Taxation (1984), p.43 who state:

When tax-exempt entities used property under these arrangements, they paid reduced rents that reflected a pass-through of investment tax incentives from the owner of the property. Tax-exempt entities thereby benefitted from investment incentives for which they did not qualify directly and effectively gained the advantage of taking income tax deductions and credits while having no corresponding liability to pay any tax on income from the property. In this way, investment incentives that were intended to reduce the tax on taxable entities were turned into unintended benefits for tax-exempt entities, including foreign entities. The benefits were equivalent to an open-ended spending program, operated within the tax system, that increased the Federal deficit, encouraged tax-exempt entities to dispose of the assets they owned and forego control over the assets they used, disordered public budgeting processes, and fed a popular perception that the tax system was open to manipulation.

The Congress was greatly concerned about these problems, the scale of which was magnified by a surge in leasing to tax-exempt entities and other arrangements devised to transfer tax benefits to them. 
This direct effect DEFRA has on tax revenues by reducing tax benefits by leasing capital by tax exempt entities is a straightforward algebraic response. Unsurprisingly, the general consensus within the public finance literature has been that federal tax revenues are increased by lowering the tax benefits of leasing by tax exempt entities. This paper contributes to the tax and public choice literature by providing evidence which suggests that when secondary effects are included, DEFRA may have, counter to its aim, reduced federal tax revenues. If more capital equipment is consumed when tax exempt entities are legally allowed to lease equipment and share the benefit of depreciation written off by a private lessor ${ }^{27}$, there are situations in which a gain in federal income tax revenue can offset the loss in federal tax revenue from depreciation being privately expensed by a lessor.

DEFRA's stated goal was to raise tax revenue, a goal any Leviathan would be expected to have. However, components of DEFRA may do the opposite and lead to lower tax collections and capital investment, harming both the public and private sector. In what follows, a theoretical analysis of leasing and the benefits of leasing by tax exempt entities are explored. It is shown that the federal government does not necessarily collect lower tax revenues by allowing tax exempt entities to benefit from leasing capital assets from firms who benefit from depreciation tax expense.

\subsection{Theory}

\subsubsection{Private Sector Leasing}

The lease versus purchase decision by a tax exempt entity is made clearer by first exploring the lease versus purchase decision of a private firm who does pay taxes and can directly depreciate capital expenditures if their choice is to purchase an asset. Consider an

\footnotetext{
${ }^{27}$ A lessor is an entity which legally owns capital assets and leases them to another firm or tax exempt entity in exchange for lease payments. A lessee is the entity which leases the equipment and makes payments to the lessor in exchange for use of a capital asset.
} 
opportunity for a given firm to invest in a capital expenditure $\mathrm{K}$ with the cash flows displayed in Table 4.1 for each in time period. The definitions of all variables are listed in Table 4.2. $\mathrm{CF}_{\text {Own }}$ are the cash flows of a firm, $\mathrm{CF}_{\mathrm{S}}$ are the cash flows to a state government, $\mathrm{CF}_{\mathrm{L}}$ are the cash flows to a local government, and $\mathrm{CF}_{\mathrm{F}}$ are the cash flows to a federal government. In the first time period the private firm pays for capital, $\mathrm{K}$ and a maintenance contract, $\mathrm{M}$, which lower taxable income. During this time period the state, local, and federal governments collect negative tax revenue due to the tax deductibility of maintenance expense and lack of firm revenue until time period 1. In time period 1through $\mathrm{S}$ the firm receives revenue from using the capital equipment, and must pay maintenance and other costs. The firm also can depreciate the cost of the asset lowering taxable income. During this time the state, local and federal governments collect income taxes. In the last time period the firm also receives revenue and expenses maintenance, depreciation, and other costs, but is additionally left with a salvage value from the after-market sale of the capital equipment.

The optimization problem for investment in capital equipment involves an inter-temporal analysis. Discounting future cash flows at the required rate of return, $r_{1}$, permits comparison of cash flows across periods and the determination as to whether the capital investment offers additional benefits that exceed additional costs. The cash flows of $\mathrm{CF}_{\text {Own }}$ are detailed in the present value terms displayed in equation (4.1), where NPV is the net present value.

$$
\begin{aligned}
N P V_{\text {Own }}=- & K-M\left(1-\tau_{1}\right) \sum_{t=0}^{S-1} \frac{1}{\left(1+r_{1}\right)^{t}}+\sum_{t=1}^{S} \frac{\left(R_{t}-C_{t}-D_{t}\right)\left(1-\tau_{1}\right)}{\left(1+r_{1}\right)^{t}}+\sum_{t=1}^{S} \frac{D_{t}}{\left(1+r_{1}\right)^{t}} \\
& +\left(\frac{1}{\left(1+r_{1}\right)^{S}}\right)\left(V_{S}-\tau_{1 C} *\left(V_{S}-V_{B S}\right)\right)
\end{aligned}
$$

To simplify, note the following: 
Let $\operatorname{PVIF} A\left(r_{i}\right) \equiv \sum_{t=1}^{S} \frac{1}{\left(1+r_{i}\right)^{t}}=\frac{1-\left(1+r_{1}\right)^{-S}}{r_{1}}$

Where PVIFA is the present value interest factor of annuity.

Let $R$ be an annuity such that $V(R)_{0}=\sum_{t=1}^{S} \frac{R_{t}}{\left(1+r_{1}\right)^{t}}=R \sum_{t=1}^{S} \frac{1}{\left(1+r_{1}\right)^{t}}$

Let $C$ be an annuity such that $V(C)_{0}=\sum_{t=1}^{S} \frac{C_{t}}{\left(1+r_{1}\right)^{t}}=C \sum_{t=1}^{S} \frac{1}{\left(1+r_{1}\right)^{t}}$

Let $D$ be an annuity such that $V(D)_{0}=\sum_{t=1}^{S} \frac{D_{t}}{\left(1+r_{1}\right)^{t}}=D \sum_{t=1}^{S} \frac{1}{\left(1+r_{1}\right)^{t}}$

Substituting these relationships (4.2) - (4.5) into (4.1) yields:

$$
\begin{array}{r}
N P V_{\text {own }}=-K+\left[\left(R-C-M\left(1+r_{1}\right)\right)\left(1-\tau_{1}\right)+\tau_{1} D\right] P V I F A\left(r_{1}\right) \\
+\left(V_{S}-\tau_{1 C} *\left(V_{S}-V_{B S}\right)\right) /\left(1+r_{1}\right)^{S}
\end{array}
$$

Equation (4.1') is thus the net present value of $\mathrm{CF}_{\text {Own }}$. In order to determine whether a firm should decide to purchase an asset, equation (4.1') must be positive and offer a higher net present value than any mutually exclusive alternative investment. As an alternative to direct purchase, it may be possible to obtain the use of capital equipment via a lease. Assume that such a lease arrangement is an operating lease that satisfies IRS guidelines. A firm should lease if a lease payment $\mathrm{L}$ is such that NPV $\geq 0$ for the lessor and the net advantage to leasing (NAL) for the lessee $=\mathrm{NPV}_{\text {Lease }}-\mathrm{NPV}_{\text {Own }}>0$. Equation (4.6) displays the present value of the cash flows received by the lessee.

$$
\begin{gathered}
N P V_{\text {Lessee }}=\left[\sum_{t=1}^{S} \frac{\left(R_{t}-C_{t}\right)\left(1-\tau_{1}\right)}{\left(1+r_{1}\right)^{t}}-L\left(1-\tau_{1}\right) \sum_{t=0}^{S-1} \frac{1}{\left(1+r_{1 d}\right)^{t}}\right] \\
=\left[R-C-L\left(1+r_{1}\right)\right]\left(1-\tau_{1}\right) \operatorname{PVIFA}\left(r_{1}\right)
\end{gathered}
$$


From (4.1') and (4.6) we find the net advantage to leasing (NAL) as:

$$
\begin{aligned}
& N A L_{\text {Lessee }}=N P V_{\text {Lease }}-N P V_{\text {Own }}= \\
& K-\left[\left(1-\tau_{1}\right)\left((L-M)\left(1+r_{1}\right)\right)+\tau_{1} D\right] P V I F A\left(r_{1}\right)+\left(V_{S}-\tau_{1 C} *\left(V_{S}-V_{B S}\right) /\left(1+r_{1}\right)^{S}\right.
\end{aligned}
$$

Even when $N A L_{\text {Lessee }}$ is positive, the lessor must also benefit from the transaction or no lease will take place. Equation (4.8) thus displays the present value of cash flows that the lessor will receive. This number must be positive or the lessor will not lease capital to the lessee.

$$
\begin{aligned}
N P V_{\text {Lessor }}= & -K+\left[\left(1-\tau_{2}\right)(L-M)\left(1+r_{2}\right)+\tau_{2} D\right] P V I F A\left(r_{2}\right)+\left(V_{S}-\tau_{2 C} *\left(V_{S}\right.\right. \\
& \left.\left.-V_{B S}\right)\right) /\left(1+r_{2}\right)^{S}
\end{aligned}
$$

Consider an opportunity for a firm in which investment in a new equipment purchase is rejected because such a capital expenditure reveals a negative net present value (i.e., $\mathrm{NPV}_{\mathrm{Own}}<$ 0). Alternatively, suppose the terms of a lease arrangement yield a positive NPV for the lessee. The 1981 ERTA worked towards liberalizing leasing for private companies in an effort to create more situations of mutually beneficial trade to incentivize capital accumulation and economic growth. Without these incentives in place, firms at the margin may have only had the opportunity to purchase capital equipment at a negative net present value, in which case to capital purchases would not occur.

In order to display this net gain to society (i.e. lessor, lessee, and the public sector) when a lease takes place, consider the following example: Example 1. Suppose new capital equipment is priced at $\$ 100,000$ at time zero. Purchase of the equipment is accompanied by a maintenance contract with a $\$ 5,000$ annual fee payable at the beginning of each year of operation. The equipment falls into the 5-year IRS MACRS class and will be used for 5 years and then sold, even though it has a useful life of 10 years. The sale of the equipment at the end of five years will be at a price equal to the book value at that time (i.e., no capital gain). Investment in the 
capital equipment is expected to increase net revenues (Sales - Expenditures) by $\$ 30,550$ per year for each of the five years of operation. The firm faces taxes at the local, state, and federal rates of $1 \%, 5 \%$, and $20 \%$, respectively and state and local taxes are deductible at the federal level. The after-tax discount rate of the firm is also $10 \%$. Cash flows for the firm are thus represented in Table 4.3. As one can see, purchase of this equipment will yield a negative NPV of $-\$ 5.72$, and as a result the firm rejects the project. Thus, there is no gain to the firm and none of the tax revenues are collected at any of the levels of government even though the taxes which would have been collected overwhelm any loss experienced by the firm.

Suppose however a potential lessor emerges with characteristics similar to the firm above except that the potential lessor faces a federal tax rate of $40 \%$, a state tax rate of $7.5 \%$, and a local tax rate of $2 \%$. As part of the 1981 ERTA, private companies were permitted to effectively trade differing tax situations through leasing to encourage capital growth. The differing tax rates between the lessor and lessee are thus used to demonstrate the benefits of leasing if certain circumstances are met. Suppose further that the potential lessor and lessee agree to a lease payment of $\$ 28,750$ per year as an annuity due, and that the lease payment includes a maintenance contract of $\$ 5,000$ paid by the lessor. In such a circumstance, the NPV for the lessor is positive and the NPV to the lessee is also positive as demonstrated by the cash flows displayed in Table 4.4 and Table 4.5. Again, for simplicity, assume that there are no capital gains.

As shown, the NPV of leasing by the lessor is $\$ 222.34$ and for the lessee is $\$ 768.56$ so the project is undertaken. Further, there are net gains to each level of government from the combined taxes net of credits to the lessor and lessee. The local government collects $\$ 499.19$ $\$ 40.75=\$ 458.44$, the state government collects $\$ 1,871.97-203.75=\$ 1,668.22$, and the federal 
government collects $\$ 9,035.39-766.12=\$ 8,269.27$, for a combined benefit to taxing authorities of $\$ 10,395.93$. The social benefit of this leasing arrangement is thus more than just the benefit between lessor and lessee, which is often all that is considered in the tax literature, and is rather the sum of the NPV of the lessor, lessee, and taxing authorities which is $\$ 11,386.83$.

Although ERTA worked to encourage leasing by private companies, the benefits of leasing under DEFRA have been reduced for tax exempt entities, and thus society. It is clear that leasing by private companies has social benefits, however DEFRA has made it nearly illegal for tax exempt entities to employ similar methods of trading tax situations with lessors. DEFRA has achieved the stated goal to reduce the indirect subsidization of tax exempt entities by discouraging the trading of tax situations with private companies. However, capital investments which would have occurred are, at the margin, reduced if the net present value of ownership is negative for the tax exempt entity and they do not have the option to lease.

The specific distribution of the gains to lessee, lessor, local government, state government, and federal government depends upon the negotiation powers of the lessee and lessor. The range of the gains can be determined. First, consider the maximum payment $\mathrm{L}_{\max }$ that a lessee would be willing and able to spend and the minimum payment $\mathrm{L}_{\min }$ that a potential lessor would accept. As long as $\mathrm{L}_{\max } \geq \mathrm{L}_{\min }$ then a lease arrangement will be possible. To determine $\mathrm{L}_{\max }$, set (4.6) equal to zero and solve for $\mathrm{L}$ :

$$
\begin{gathered}
L_{\max }=\left[K+\left[\left(1-\tau_{2}\right) M\left(1+r_{2}\right)-\tau_{2} D\right] P \operatorname{VIFA}\left(r_{2}\right)-\left(\frac{1}{\left(1+r_{2}\right)^{S}}\right)\left(V_{S}-\tau_{2 C} *\left(V_{S}\right.\right.\right. \\
\left.\left.\left.-V_{B S}\right)\right)\right] /\left[\left(1-\tau_{2}\right)\left(1+r_{2}\right) \operatorname{PVIFA}\left(r_{2}\right)\right]
\end{gathered}
$$

Similarly, determine $\mathrm{L}_{\min }$ by setting (4.8) equal to zero, which yields: 


$$
\begin{gathered}
L_{\text {min }}=\left[K+\left[\left(1-\tau_{2}\right) M\left(1+r_{2}\right)-\tau_{2} D\right] \operatorname{PVIFA}\left(r_{2}\right)-\left(\frac{1}{\left(1+r_{2}\right)^{S}}\right)\left(V_{S}-\tau_{2 C} *\left(V_{S}\right.\right.\right. \\
\left.\left.-V_{B S}\right)\right] /\left[\left(1-\tau_{2}\right)\left(1+r_{2}\right) \operatorname{PVIFA}\left(r_{2}\right)\right]
\end{gathered}
$$

In the current example $\mathrm{L}_{\max }$ is calculated to be $\$ 28,976$ and $\mathrm{L}_{\min }$ is calculated to be $\$ 28,660$. Since the assumed lease payment of $\$ 28,750$ falls within this range, both lessor and lessee benefit and would enter into a lease contract. The difference between the two, $\$ 316$, can be negotiated between the lessor and lessee, and depending upon the negotiation power of each, will result in different net present values for the two. However, as long as the lease payment stays within the range of $\mathrm{L}_{\max }$ and $\mathrm{L}_{\min }$, the lease is mutually beneficial and will take place.

\subsubsection{Public Sector Leasing}

It is clear from the previous analysis that leasing by the private sector can lead to Pareto optimal social gains. The federal government thus encourages leasing by private firms through investment tax credits, accelerated depreciation methods, etc., on leased property. It stands to reason then that this benefit could also lead to Pareto improvements if tax exempt entities could claim similar credits and benefit from leasing. Before DEFRA 1984 tax-exempt entities were encouraged to lease through the tax codes since direct purchases by tax-exempt entities are not subject to depreciation tax expense. By leasing from a private company who can benefit from depreciation tax expense, tax-exempt entities were able to lease at a lower present value cost compared to a purchase. As this led directly to increased tax credits and lower tax revenues by governments, DEFRA was enacted to stop these indirect subsidies to tax-exempt entities who were inflating their budgets synthetically. However, the indirect effect DEFRA has had on the decision of tax-exempt entities to pursue the use of capital equipment, either through purchase or lease, has not been analyzed. In what follows, it is shown that DEFRA discourages capital 
investment in projects which would have been undertaken if leasing were an option, but otherwise would not be pursued by direct purchase. This can lead to a decrease in overall tax revenues if income taxes are lessened by a reduction in capital projects and taxable income. Society as a whole will thus lose out.

To illustrate this, suppose that a business entity operates in the public sector, such as a forensic science laboratory, instead of the private sector. As stated, DEFRA placed some limitations on the ability of public sector agencies use of leasing. Key features include the requirement for straight-line depreciation methods, no investment tax credit allowance, and limitations on the term of the lease versus the engineering life of the capital investment.

Reconsider Example 1 with the purchaser and user of the capital equipment being a public sector agency and the annual net gain $(\mathrm{R}-\mathrm{C})=\$ 31,880$, such that the net present value is equal to zero. ${ }^{28}$ In such a case the public sector agency will be indifferent between pursuing the project or not. The cash flows to the public sector lessee are displayed in Table 4.6.

Suppose that the agency in question is a part of state government. The present value of the net budget is zero for each level of government. That is, there are no tax revenues to local or federal governments and the state government receives net benefits that are identical to its budget outlays.

Now, suppose that a lessor offers to purchase and then lease the equipment to the state government agency via an annuity due of $\$ 30,000$ following the conditions outlined in Example 1. In order for a leasing contract to be considered, it must be the case that the net present cost of the lease is lower for the state government than direct purchase and simultaneously, the private sector lessor must realize a positive net present value from this action. In this case, both parties

\footnotetext{
${ }^{28}$ Instead of a direct revenue collection, the $\mathrm{R}$ presents value or dollar benefits to the jurisdiction such that the present value of net benefits are equal to the present value of expenditures
} 
benefit. Assume initially that the lessee and lessor reside in the same local tax jurisdiction. The lessee's cash flows are shown in Table 4.7, and the lessor's cash flows are shown in Table 4.8. In this case the lessee does not pay taxes or receive tax benefits, so the cash flows come from net revenues minus the lease payment only. The lessor, after maintenance costs, depreciation, and all taxes is able to lease the equipment at a profit to the tax-exempt entity. The lessor experiences a positive net present value with gains of $\$ 435.73$, and the lessee experiences a direct benefit through use of capital equipment of $\$ 876.68$. Since both the lessor and lessee have positive net present values, the project is pursued which otherwise may not have occurred without a lease. The various governments also receive net benefits. The local government receives $\$ 568.62$, the state government receives $\$ 1,421.55$ in tax revenue and $\$ 876.68$ in benefits from the use of capital equipment for a total gain of $\$ 2,298.22$, and the federal government receives $\$ 10,576.30$ in tax revenue. The net gain for all government levels and to the private lessor from leasing over public sector ownership is $\$ 13,878.87$. There is thus a Pareto improvement, as it is shown society as a whole can benefit when tax exempt entities lease and share in the benefit from depreciation tax expense. Without the option to lease at a lower net present value than purchase, the capital expenditure would not have occurred and no taxes would have been collected. Although tax exempt entities continue to lease after DEFRA, the response at the margin has been a reduction in leasing and thus lower tax revenues by governments.

As before, the distribution of gains depends upon the negotiation power of the lessor and lessee. $\mathrm{L}_{\min }$ remains the same symbolically, however to solve for $\mathrm{L}_{\max }$ we set (4.6) equal to zero again and solve for $\mathrm{L}$ assuming $\tau_{1}$ is zero, since tax-exempt entities have a tax rate of zero, yielding equation (4.11). 
$L_{\text {max }}=\left[K+\left[M\left(1+r_{1}\right)\right] \operatorname{PVIFA}\left(r_{1}\right)-\left(\frac{1}{\left(1+r_{1}\right)^{S}}\right)\left(V_{S}\right)\right] /\left[\left(1+r_{1}\right) \operatorname{PVIFA}\left(r_{1}\right)\right]$

For this example, $\mathrm{L}_{\min }$ is calculated to be $\$ 29,827$ and $\mathrm{L}_{\max }$ is calculated to be $\$ 30,194$. Since the assumed lease payment of $\$ 30,000$ falls within this range, both lessor and lessee benefit and would enter into the lease contract.

Traditionally the finance and public finance literature exploring leasing has focused on situations where two entities with different circumstances, such as tax situations, can enter into a lease where the market value of the two entities can be greater than both entities acting alone (Lewellen et al. 1976). This current paper agrees, however it departs from the previous literature on a second key point which the previous literature ignores. The direct algebraic response to a reduction in depreciation benefits by tax exempt entities has been that the federal government reduces the indirect subsidization of capital and as a result increases net tax revenues. The literature therefore suggests that the Internal Revenue Service discourages leasing by tax-exempt, which in reality has taken the form of DEFRA. This reduction in depreciation tax benefits would be beneficial to the federal government if secondary effects did not occur. However, secondary effects do occur, and as shown above, the result of such policies has been a reduction of income taxes when, at the margin, capital investments and thus income are reduced.

\subsection{Conclusion and Policy Recommendation}

The Leviathan model of government suggests that governments, when unconstrained by a constitutional limit on their taxing authority, will act in such a way as to maximize tax revenues. The findings in this paper suggest however that government can, and in the case of one provision in the Deficit Reduction Act (DEFRA) of 1984 do, act in ways that decrease tax revenue at the margin. The Leviathan model as a general explanation of government behavior is thus 
incomplete. Public finance economists have explained that the public sector may be smaller when federal rather than local governments provide public goods due to the advantage of economies of scale, or through the expression of voter preferences. This paper adds to the literature by providing theoretical evidence that federal governments also reduce tax revenues by either ineffective tax policy, or by attempting to optimize something else such as power over state or municipal budgets in the case of DEFRA.

Indeed, in the 2008 presidential debates when then Senator Barack Obama was asked by Charles Gibson of $\mathrm{ABC}$ whether capital gains taxes should be raised, Obama responded "well Charlie, what I've said is that I would look at raising the capital gains tax for purposes of fairness." Optimizing "fairness" in the case of capital gains tax has historically decreased tax revenue by the federal government. The Leviathan model is thus an imperfect explanation for government behavior, given the real world examples of governments acting counter to a goal of revenue maximization 


\section{Table 4.1: Cash Flows Derived from Purchasing a Capital Asset ${ }^{29}$}

\begin{tabular}{llll} 
Time & \multicolumn{1}{c}{0} & \multicolumn{1}{c}{1 through S-1 } & \multicolumn{1}{c}{$S$} \\
\hline $\mathrm{CF}_{\mathrm{Own}}$ & $-\mathrm{K}-\mathrm{M}\left(1-\tau_{1}\right)$ & $\left(1-\tau_{1}\right)\left(\mathrm{R}_{\mathrm{t}}-\mathrm{C}_{\mathrm{t}}-\mathrm{M}-\mathrm{D}_{\mathrm{t}}\right)+\mathrm{D}_{\mathrm{t}}$ & $\left(1-\tau_{1}\right)\left(\mathrm{R}_{\mathrm{t}}-\mathrm{C}_{\mathrm{t}}-\mathrm{D}_{\mathrm{t}}\right)+\mathrm{D}_{\mathrm{t}}+\mathrm{V}_{\mathrm{S}}-\tau_{1 \mathrm{C}}\left(\mathrm{V}_{\mathrm{S}}-\mathrm{V}_{\mathrm{BS}}\right)$ \\
\hline $\mathrm{CF}_{\mathrm{S}}$ & $\tau_{1 \mathrm{~S}} \mathrm{M}$ & $\tau_{1 \mathrm{~S}}\left(\mathrm{R}_{\mathrm{t}}-\mathrm{C}_{\mathrm{t}}-\mathrm{M}-\mathrm{D}_{\mathrm{t}}\right)$ & $\tau_{1 \mathrm{~S}}\left(\mathrm{~V}_{\mathrm{S}}-\mathrm{V}_{\mathrm{BS}}\right)$ \\
\hline $\mathrm{CF}_{\mathrm{L}}$ & $\tau_{1 \mathrm{~L}} \mathrm{M}$ & $\tau_{1 \mathrm{~L}}\left(\mathrm{R}_{\mathrm{t}}-\mathrm{C}_{\mathrm{t}}-\mathrm{M}-\mathrm{D}_{\mathrm{t}}\right)$ & $\tau_{1 \mathrm{~L}}\left(\mathrm{~V}_{\mathrm{S}}-\mathrm{V}_{\mathrm{BS}}\right)$ \\
\hline $\mathrm{CF}_{\mathrm{F}}$ & $\tau_{1 \mathrm{~F}} \mathrm{M}\left(1-\tau_{1 \mathrm{~S}}-\tau_{1 \mathrm{~L}}\right)$ & $\tau_{1 \mathrm{~F}}\left(\mathrm{R}_{\mathrm{t}}-\mathrm{C}_{\mathrm{t}}-\mathrm{M}-\mathrm{D}_{\mathrm{t}}\right)\left(1-\tau_{1 \mathrm{~S}}-\tau_{1 \mathrm{~L}}\right)$ & $\left(\tau_{1 \mathrm{CF}}-\tau_{1 \mathrm{~F}}\right)\left(\tau_{1 \mathrm{~L}}+\tau_{1 \mathrm{~S}}\right)\left(\mathrm{V}_{\mathrm{S}}-\mathrm{V}_{\mathrm{BS}}\right)$ \\
\hline
\end{tabular}

\footnotetext{
${ }^{29}$ Table 4.1 summarizes the cash flows (CF) of owners of capital goods, and the resulting cash flows of state governments (s), local governments (l), and federal governments (f) for time periods 0 through S. Variable definitions for the equations in Table 4.1 are found in Table 4.2.
} 
Table 4.2: Variable Definitions ${ }^{30}$

\begin{tabular}{|c|c|}
\hline Variable & Definition \\
\hline $\mathrm{K}$ & Retail Capital Cost of New Equipment \\
\hline$\alpha$ & Percentage discount from Retail Capital Cost of New Equipment \\
\hline M & Annual retail cost of maintenance contract \\
\hline$\beta$ & Percentage discount from retail cost of maintenance contract \\
\hline $\mathrm{L}$ & Annual lease payment from lessor to lessee \\
\hline $\mathrm{R}_{\mathrm{t}}$ & Revenue to user of equipment at time $t$ \\
\hline $\mathrm{C}_{\mathrm{t}}$ & Cost (other than Depreciation or Maintenance) at time $t$ \\
\hline $\mathrm{D}_{\mathrm{t}}$ & Depreciation allowance in time $t$ \\
\hline S & Length of lease contract \\
\hline $\mathrm{N}$ & Depreciation class \\
\hline $\mathrm{V}_{\mathrm{S}}$ & Salvage value (retail) at time $S$ \\
\hline $\mathrm{V}_{\mathrm{BS}}$ & Book value at time $S$ \\
\hline$\gamma$ & Percentage salvage value premium above retail by wholesaler \\
\hline$\tau_{1}$ & Lessee tax rate (combined federal, state, \& local) for ordinary income \\
\hline$\tau_{1 \mathrm{~F}}$ & Lessee federal tax rate for ordinary income \\
\hline$\tau_{1 \mathrm{~s}}$ & Lessee state tax rate for ordinary income \\
\hline$\tau_{1 \mathrm{~L}}$ & Lessee local tax rate for ordinary income \\
\hline$\tau_{1 \mathrm{c}}$ & Lessee tax rate (combined federal, state, $\&$ local) for capital gain income \\
\hline$\tau_{1 \mathrm{CF}}$ & Lessee federal tax rate for capital gain income \\
\hline$\tau_{1 \mathrm{CS}}$ & Lessee state tax rate for capital gain income \\
\hline$\tau_{1 \mathrm{CL}}$ & Lessee local tax rate for capital gain income \\
\hline$\tau_{2}$ & Lessor tax rate (combined federal, state, \& local) for ordinary income \\
\hline$\tau_{2 \mathrm{~F}}$ & Lessor federal tax rate for ordinary income \\
\hline$\tau_{2 S}$ & Lessor state tax rate for ordinary income \\
\hline$\tau_{2 \mathrm{~L}}$ & Lessor local tax rate for ordinary income \\
\hline$\tau_{2 c}$ & Lessor tax rate (combined federal, state, \& local) for capital gain income \\
\hline$\tau_{2 \mathrm{CF}}$ & Lessor federal tax rate for capital gain income \\
\hline$\tau_{2 \mathrm{CS}}$ & Lessor state tax rate for capital gain income \\
\hline$\tau_{2 \mathrm{CL}}$ & Lessor local tax rate for capital gain income \\
\hline $\mathrm{r}_{1}$ & discount rate for lessee (weighted average cost of capital) \\
\hline$r_{1 d}$ & interest rate on debt for lessee \\
\hline$r_{2}$ & discount rate for lessor \\
\hline$r_{2 d}$ & interest rate on debt for lessor \\
\hline $\mathrm{r}_{\mathrm{Fd}}$ & interest rate on debt for federal government \\
\hline$r_{S d}$ & interest rate on debt for state/provincial government \\
\hline $\mathrm{r}_{\mathrm{Ld}}$ & interest rate on debt for local government \\
\hline
\end{tabular}

${ }^{30}$ Table 4.2 lists the variable definitions for the equations (1) through (11) and for the equations in Table 4.1. 
Table 4.3: Cash Flows from the Purchase of a Capital Asset by a Firm ${ }^{31}$

\begin{tabular}{lcccccc}
\multicolumn{1}{c}{ Time } & 0 & 1 & 2 & 3 & 4 & 5 \\
\hline Equipment & $-\$ 100,000$ & & & & & \\
Maintenance & $-\$ 5,000$ & $-\$ 5,000$ & $-\$ 5,000$ & $-\$ 5,000$ & $-\$ 5,000$ & \\
Net Revenue & & $\$ 30,550$ & $\$ 30,550$ & $\$ 30,550$ & $\$ 30,550$ & $\$ 30,550$ \\
Depreciation & & $-\$ 20,000$ & $-\$ 32,000$ & $-\$ 19,200$ & $-\$ 11,520$ & $-\$ 11,520$ \\
Operating Profit & $-\$ 5,000$ & $\$ 5,550$ & $-\$ 6,450$ & $\$ 6,350$ & $\$ 14,030$ & $\$ 19,030$ \\
Tax State & $\$ 250$ & $-\$ 278$ & $\$ 323$ & $-\$ 318$ & $-\$ 702$ & $-\$ 952$ \\
Tax Local & $\$ 50$ & $-\$ 56$ & $\$ 65$ & $-\$ 64$ & $-\$ 140$ & $-\$ 190$ \\
Tax Federal & $\$ 940$ & $-\$ 1,043$ & $\$ 1,213$ & $-\$ 1,194$ & $-\$ 2,638$ & $-\$ 3,578$ \\
Salvage & & & & & & $\$ 5,760$ \\
Tax Cap Gain State & & & & & & \\
Tax Cap Gain Local & & & & & & \\
Tax Cap Gain Federal & & & & & & \\
\hline Cash Flow & $-\$ 103,760$ & $\$ 24,174$ & $\$ 27,150$ & $\$ 23,975$ & & \\
\multicolumn{1}{c}{} & & & & & &
\end{tabular}

\footnotetext{
${ }^{31}$ Table 4.3 displays the cash flows resulting from a firm purchasing a capital asset. The net present value (NPV) of this purchase for the firm is $\mathbf{\$} \$ 5.72$, which suggests that the firm will not pursue the purchase of the asset. The NPV of taxes collected had this asset been purchased would however be positive and greater than any losses the firm would have experienced. Thus this socially beneficial project does not occur.
} 
Table 4.4: Cash Flows a Lessor Receives by Leasing to a Firm ${ }^{32}$

\begin{tabular}{|c|c|c|c|c|c|c|}
\hline Time & 0 & 1 & 2 & 3 & 4 & 5 \\
\hline Equipment & $-\$ 100,000$ & & & & & \\
\hline Maintenance & $-\$ 5,000$ & $-\$ 5,000$ & $-\$ 5,000$ & $-\$ 5,000$ & $-\$ 5,000$ & \\
\hline Lease payment & $\$ 28,750$ & $\$ 28,750$ & $\$ 28,750$ & $\$ 28,750$ & $\$ 28,750$ & \\
\hline Depreciation & & $-\$ 20,000$ & $-\$ 32,000$ & $-\$ 19,200$ & $-\$ 11,520$ & $-\$ 11,520$ \\
\hline Operating Profit & $\$ 23,750$ & $\$ 3,750$ & $-\$ 8,250$ & $\$ 4,550$ & $\$ 12,230$ & $-\$ 11,520$ \\
\hline Tax State & $-\$ 1,781$ & $-\$ 281$ & $\$ 619$ & $-\$ 341$ & $-\$ 917$ & $\$ 864$ \\
\hline Tax Local & $-\$ 475$ & $-\$ 75$ & $\$ 165$ & $-\$ 91$ & $-\$ 245$ & $\$ 230$ \\
\hline Tax Federal & $-\$ 8,598$ & $-\$ 1,358$ & $\$ 2,987$ & $-\$ 1,647$ & $-\$ 4,427$ & $\$ 4,170$ \\
\hline Salvage & & & & & & $\$ 5,760$ \\
\hline \multicolumn{7}{|l|}{ Tax Cap Gain State } \\
\hline \multicolumn{7}{|c|}{ Tax Cap Gain Local } \\
\hline \multicolumn{7}{|c|}{ Tax Cap Gain Federal } \\
\hline Cash Flow & $-\$ 87,104$ & $\$ 22,037$ & $\$ 27,522$ & $\$ 21,674$ & $\$ 18,165$ & $\$ 11,030$ \\
\hline NPV & $\$ 222.34$ & & & & & \\
\hline NPV Tax State & $\$ 1,872$ & & & & & \\
\hline NPV Tax Local & $\$ 499$ & & & & & \\
\hline NPV Tax Federal & $\$ 9,035$ & & & & & \\
\hline
\end{tabular}

\footnotetext{
${ }^{32}$ Table 4.4 displays the cash flows a leasing company receives from leasing an asset to a firm. The NPV received by the lessor is positive, and as shown in Table 5 the NPV received by the lessee is also positive, suggesting the lease will take place. As a result the local, state, and federal governments collect net positive taxes.
} 
Table 4.5: Cash Flows a Firm Receives from Leasing ${ }^{33}$

\begin{tabular}{|c|c|c|c|c|c|c|}
\hline Time & 0 & 1 & 2 & 3 & 4 & 5 \\
\hline \multicolumn{7}{|l|}{ Equipment } \\
\hline \multicolumn{7}{|l|}{ Maintenance } \\
\hline Net Revenue & & $\$ 30,550$ & $\$ 30,550$ & $\$ 30,550$ & $\$ 30,550$ & $\$ 30,550$ \\
\hline Lease payment & $-\$ 28,750$ & $-\$ 28,750$ & $-\$ 28,750$ & $-\$ 28,750$ & $-\$ 28,750$ & \\
\hline \multicolumn{7}{|l|}{ Depreciation } \\
\hline Operating Profit & $-\$ 28,750$ & $\$ 1,800$ & $\$ 1,800$ & $\$ 1,800$ & $\$ 1,800$ & $\$ 30,550$ \\
\hline Tax State & $\$ 1,438$ & $-\$ 90$ & $-\$ 90$ & $-\$ 90$ & $-\$ 90$ & $-\$ 1,528$ \\
\hline Tax Local & $\$ 288$ & $-\$ 18$ & $-\$ 18$ & $-\$ 18$ & $-\$ 18$ & $-\$ 306$ \\
\hline Tax Federal & $\$ 5,405$ & $-\$ 338$ & $-\$ 338$ & $-\$ 338$ & $-\$ 338$ & $-\$ 5,743$ \\
\hline \multicolumn{7}{|l|}{ Salvage } \\
\hline \multicolumn{7}{|c|}{ Tax Cap Gain State } \\
\hline \multicolumn{7}{|c|}{ Tax Cap Gain Local } \\
\hline \multicolumn{7}{|c|}{ Tax Cap Gain Federal } \\
\hline Cash Flow & $-\$ 21,620$ & $\$ 1,354$ & $\$ 1,354$ & $\$ 1,354$ & $\$ 1,354$ & $\$ 22,974$ \\
\hline NPV & $\$ 768.56$ & & & & & \\
\hline NPV Tax State & $-\$ 204$ & & & & & \\
\hline NPV Tax Local & $-\$ 41$ & & & & & \\
\hline NPV Tax Federal & $-\$ 766$ & & & & & \\
\hline
\end{tabular}

\footnotetext{
${ }^{33}$ Table 4.5 displays the cash flows a firm receives from leasing an asset from a leasing company. The NPV received by the lessee is positive, and as shown in Table 4 the NPV received by the lessor is also positive, suggesting the lease will take place. As a result the local, state, and federal governments collect net positive taxes.
} 
Table 4.6: Cash Flows from the Purchase of a Capital Asset by a Public Sector Agency ${ }^{34}$

\begin{tabular}{|c|c|c|c|c|c|c|}
\hline Time & 0 & 1 & 2 & 3 & 4 & 5 \\
\hline Equipment & $-\$ 100,000$ & & & & & \\
\hline Maintenance & $-\$ 5,000$ & $-\$ 5,000$ & $-\$ 5,000$ & $-\$ 5,000$ & $-\$ 5,000$ & \\
\hline Net Revenue & & $\$ 31,880$ & $\$ 31,880$ & $\$ 31,880$ & $\$ 31,880$ & $\$ 31,880$ \\
\hline Lease payment & $\$ 0$ & $\$ 0$ & $\$ 0$ & $\$ 0$ & $\$ 0$ & \\
\hline Depreciation & & $-\$ 20,000$ & $-\$ 20,000$ & $-\$ 20,000$ & $-\$ 20,000$ & $-\$ 20,000$ \\
\hline Operating Profit & $-\$ 5,000$ & $\$ 6,880$ & $\$ 6,880$ & $\$ 6,880$ & $\$ 6,880$ & $\$ 11,880$ \\
\hline Tax State & $\$ 0$ & $\$ 0$ & $\$ 0$ & $\$ 0$ & $\$ 0$ & $\$ 0$ \\
\hline Tax Local & $\$ 0$ & $\$ 0$ & $\$ 0$ & $\$ 0$ & $\$ 0$ & $\$ 0$ \\
\hline Tax Federal & $\$ 0$ & $\$ 0$ & $\$ 0$ & $\$ 0$ & $\$ 0$ & $\$ 0$ \\
\hline Salvage & & & & & & $\$ 0$ \\
\hline \multicolumn{7}{|l|}{ Tax Cap Gain State } \\
\hline \multicolumn{7}{|l|}{ Tax Cap Gain Local } \\
\hline \multicolumn{7}{|c|}{ Tax Cap Gain Federal } \\
\hline Cash Flow & $-\$ 105,000$ & $\$ 26,880$ & $\$ 26,880$ & $\$ 26,880$ & $\$ 26,880$ & $\$ 31,880$ \\
\hline NPV & $\$ 0.00$ & & & & & \\
\hline NPV Tax State & $\$ 0$ & & & & & \\
\hline NPV Tax Local & $\$ 0$ & & & & & \\
\hline NPV Tax Federal & $\$ 0$ & & & & & \\
\hline
\end{tabular}

\footnotetext{
${ }^{34}$ Table 4.6 displays the cash flows a tax exempt entity would receive from purchasing a capital asset. Since tax exempt entities do not pay taxes they cannot claim depreciation as a tax deductable expense and are forced to pay the full price for the asset. Given the parameters defined in this paper, the result is a NPV=0, suggesting the tax exempt entity is indifferent between purchasing and not purchasing the asset.
} 
Table 4.7: Cash Flows a Public Sector Agency Receives from Leasing ${ }^{35}$

\begin{tabular}{lcccccc}
\multicolumn{1}{c}{ Time } & 0 & 1 & 2 & 3 & 4 & 5 \\
\hline Equipment & & & & & & \\
Maintenance & & & & & & \\
Net Revenue & & $\$ 31,880$ & $\$ 31,880$ & $\$ 31,880$ & $\$ 31,880$ & $\$ 31,880$ \\
Lease payment & $-\$ 30,000$ & $-\$ 30,000$ & $-\$ 30,000$ & $-\$ 30,000$ & $-\$ 30,000$ & \\
Depreciation & & & & & & \\
Operating Profit & $-\$ 30,000$ & $\$ 1,880$ & $\$ 1,880$ & $\$ 1,880$ & $\$ 1,880$ & $\$ 31,880$ \\
Tax State & $\$ 0$ & $\$ 0$ & $\$ 0$ & $\$ 0$ & $\$ 0$ & $\$ 0$ \\
Tax Local & $\$ 0$ & $\$ 0$ & $\$ 0$ & $\$ 0$ & $\$ 0$ & $\$ 0$ \\
Tax Federal & $\$ 0$ & $\$ 0$ & $\$ 0$ & $\$ 0$ & $\$ 0$ & $\$ 0$ \\
Salvage & & & & & & $\$ 0$ \\
Tax Cap Gain State & & & & & & \\
Tax Cap Gain Local & & & & & & \\
Tax Cap Gain Federal & & & & & & \\
\hline Cash Flow & $-\$ 30,000$ & $\$ 1,880$ & $\$ 1,880$ & $\$ 1,880$ & $\$ 1,880$ & $\$ 31,880$ \\
& & & & & & \\
NPV & $\$ 876.68$ & & & & & \\
NPV Tax State & $\$ 0$ & & & & & \\
NPV Tax Local & $\$ 0$ & & & & & \\
NPV Tax Federal & $\$ 0$ & & & & &
\end{tabular}

\footnotetext{
${ }^{35}$ Table 4.7 shows the cash flows a tax exempt entity would receive if they were able to lease capital equipment from a lessor. As one can see the tax exempt lessee has a positive NPV, and as shown in Table 8 the lessor also has a positive NPV, suggesting the lease should take place. If the lease takes place the federal, state, and local taxing authorities will collect the positive net taxes shown in Table 8 . The degree to which tax policy discourages this lease however will result, at the margin, of lower income tax revenues by the three levels of government.
} 
Table 4.8: Cash Flows a Lessor Receives by Leasing to a Public Sector Agency ${ }^{36}$

\begin{tabular}{lrrrrrr}
\multicolumn{1}{c}{ Time } & \multicolumn{1}{c}{1} & \multicolumn{1}{c}{2} & \multicolumn{1}{c}{3} & \multicolumn{1}{c}{4} & \multicolumn{1}{c}{5} \\
\hline Equipment & $-\$ 100,000$ & & & & & \\
Maintenance & $-\$ 5,000$ & $-\$ 5,000$ & $-\$ 5,000$ & $-\$ 5,000$ & $-\$ 5,000$ & \\
Lease payment & $\$ 30,000$ & $\$ 30,000$ & $\$ 30,000$ & $\$ 30,000$ & $\$ 30,000$ & \\
Depreciation & & $-\$ 20,000$ & $-\$ 20,000$ & $-\$ 20,000$ & $-\$ 20,000$ & $-\$ 20,000$ \\
Operating Profit & $\$ 25,000$ & $\$ 5,000$ & $\$ 5,000$ & $\$ 5,000$ & $\$ 5,000$ & $-\$ 20,000$ \\
Tax State & $-\$ 1,250$ & $-\$ 250$ & $-\$ 250$ & $-\$ 250$ & $-\$ 250$ & $\$ 1,000$ \\
Tax Local & $-\$ 500$ & $-\$ 100$ & $-\$ 100$ & $-\$ 100$ & $-\$ 100$ & $\$ 400$ \\
Tax Federal & $-\$ 9,300$ & $-\$ 1,860$ & $-\$ 1,860$ & $-\$ 1,860$ & $-\$ 1,860$ & $\$ 7,440$ \\
Salvage & & & & & & \\
Tax Cap Gain State & & & & & & \\
Tax Cap Gain Local & & & & & & \\
Tax Cap Gain Federal & & & & & & \\
\hline Cash Flow & $-\$ 86,050$ & $\$ 22,791$ & $\$ 22,792$ & $\$ 22,793$ & & \\
& & & & & &
\end{tabular}

\footnotetext{
${ }^{36}$ Table 4.8 shows the cash flows a lessor would receive if they were able to lease capital equipment to a tax exempt entity. As one can see the lessor has a positive NPV, and as shown in Table 7 the tax exempt lessee also has a positive NPV, suggesting the lease should take place. If the lease takes place the federal, state, and local taxing authorities will collect the positive net taxes shown in Table 8 . The degree to which tax policy discourages this lease however will result, at the margin, of lower income tax revenues by the three levels of government.
} 


\section{References}

Ando, A., \& Modigliani, F. (1963). The "life cycle" hypothesis of saving: Aggregate implications and tests. The American Economic Review, 53(1): 55-84.

Benson, B. (1998). To serve and protect: Privatization and community in criminal justice. New York: New York University Press.

Bergstrom, T. C., \& Goodman, R. P. (1973). Private demands for public goods. The American Economic Review, 63(3): 280-296.

Blose, L. E., \& Martin, J. D. (1989). Federal government leasing: Cost, incentives, and effects. Public Budgeting \& Finance, 66-75.

Borcherding, T. E., \& Deacon, R. T. (1972). The demand for the services of non-federal governments. The American Economic Review, 62(5): 891-901.

Borcherding, T. E., Bush, W. C., \& Spann, R. M. (1977). The effects on the public spending of the divisibility of public outputs in consumption, bureaucratic power, and the size of the tax-sharing group. In Budgets and Bureaucrats. Durham, NC: Duke University Press.

Brennan, G., \& Buchanan, J. (1980). The power to tax: Analytical foundations of a fiscal constitutions. Cambridge: Cambridge University Press.

Buchanan, J. M. (1965). An economic theory of clubs. Economica, 32(125): 1-14.

Callahan, J. (1981). The lease versus purchase decision in the public sector. National Tax Journal, 34(2): 235-240.

Cameron, A. C., \& Trivedi, P. K. (2009). Microeconometrics: Methods and Applications. New York: Cambridge University Press.

Cameron, D. R. (1978). The expansion of the public economy: A comparative analysis. American Political Science Review, 72(4): 1243-1261. 
Campbell, C. D. (1994). New Hampshire's tax-base limits: An example of the Leviathan model. Public Choice, 78(2): 129-144.

Christofferson, H., Paldam, M., \& Wurtz, A. H. (2007). Public versus private production and economies of scale. Public Choice, 130: 311-328.

Coase, R. H. (1974). The lighthouse in economics. The Journal of Law and Economics, 17(2): $357-376$.

Congleton, R. D., \& Bennett, R. W. (1995). On the political economy of state highway expenditures: Some evidence of the relative performance of alternative public choice models. Public Choice, 84(1-2): 1-24.

Congleton, R. D., \& Shughart, W. F. (1990). The growth of social security: Electoral push or political pull? Economic Inquiry, 28(1): 109-132.

Deacon, R. T. (1979). The expenditure effects of alternative public supply institutions. Public Choice, 34(3-4): 381-397.

Deno, K. T., \& Mehay, S. L. (1987). Municipal management structure and fiscal performance: Do city managers make a difference? Southern Economic Journal, 53(3): 627-642.

Deutsch, J., Hakim, S., \& Weinblatt, J. (1984). Interjurisdictional criminal mobility: A theoretical perspective. Urban Studies, 21: 451-458.

Doleac, J. (2012). The effects of DNA databases on crime. Working Paper.

Feld, L. P., Kirchgassner, G., \& Schaltegger, C. A. (2010). Decentralized taxation and the size of government: Evidence from Swiss state and local governments. Southern Economic Journal, 77(1): 27-48.

Gonzalez, R. A., \& Mehay, S. L. (1985). Bureaucracy and the divisibility of local public output. Public Choice, 45: 89-101. 
Heames, J. T. (2011). Forensic science staffing: Creating a work formula. Forensic Science Policy \& Management: An International Journal, 2(1): 5-10.

Holcombe, R. G. (1996). Public Finance: Government Revenues and Expenditures in the United States Economy. St. Paul, Minn.: West Publishing.

Holcombe, R. G., \& Sobel, R. S. (1995). Empirical evidence on the publicness of state legislative activities. Public Choice, 83(1-2): 47-58.

Houck, M. M., \& Siegel, J. A. (2010). Fundamentals of Forensic Science. Burlington, MA: Academic Press.

Houck, M. M., Riley, R. A., Speaker, P. J., \& Witt, T. S. (2009). FORESIGHT: A Business Approach to Improving Forensic Science Services. Forensic Science Policy \& Management: An International Journal, 1(2): 85-95.

Joint Committee on Taxation (1984). General Explanation Of The Revenue Provisions Of The Deficit Reduction Act Of 1984. H.R.4170, 98th Congress; Public Law 98-369.

King, K. A. (2007). Do spillover benefits create a market inefficiency in K-12 public education? Cato Journal, 27(1): 447-458.

Knapp, M. (1982). Economies of scale in local public services: the case of British crematoria. Applied Economics, 14(5): 447-453.

Lewellen, W. G., Long, M.S., \& McConnell, J. J. (1976) Asset leasing in competitive capital markets. The Journal of Finance, 31(3): 787-798.

Maguire, C., Houck, M. M., Williams, R., \& Speaker, P. J. (2012). Efficiency and the costeffective delivery of forensic science services: Insourcing, outsourcing, and privatization. Forensic Science Policy and Management: An International Journal, 3: 62-69.

Marlow, M. L. (1988). Fiscal decentralization and government size. Public Choice, 56: 259-269. 
Martinez-Vazquez, J., \& Yao, M. H. (2009). Fiscal decentralization and public sector employment: A cross-country analysis. Public Finance Review, 37(5): 539-571.

Masse, I., Hanrahan, J. R., \& Kushner, J. (1988). The effect of changes in tax legislation on the purchase/lease decision in the public sector. National Tax Journal, 41(1): 122-130.

Mathers, R. (2009). The spillover benefits of AIDs prevention. Journal of Public Finance and Public Choice, 27(1) 45-61.

McAndrew, W. P. (2012). Are forensic science services club goods? An analysis of the optimal forensic science service delivery model. Forensic Science Policy and Management: An International Journal, 3(4): 151-158.

McAndrew, W. P. (2012). Is privatization inevitable for forensic science laboratories? Forensic Science Policy and Management: An International Journal, 3(1): 42-52.

Mehay, S. L. (1984). The effect of governmental structure on special district expenditure. Public Choice, 44(2): 339-348.

Mueller, D. C., \& Stratmann, T. (2003). The economic effects of democratic participation. Journal of Public Economics, 87(9-10): 2129-2155.

Musgrave, R. (1981). Leviathan cometh- or does he? In H. Ladd, \& T. N. Tideman, Tax and Expenditure Limitations, COUPE Papers on Public Economics, 5 (pp. 77-120). Washington: The Urban Institute.

Nelson, A. C., \& Foster, K. A. (1999). Metropolitan governance structure and income growth. Journal of Urban Affairs, 21(3): 309-324.

Nelson, M. A. (1986). An empirical analysis of state and local tax structure in the context of the Leviathan model of government. Public Choice, 49: 283-294.

Niskanen, W. A. (1971). Bureaucracy and representative government. Chicago: Aldine-Atherton. 
Oates, W. E. (1988). On the measurement of congestion in the provision of local public goods. Journal of Urban Economics, 24(1): 85-94.

Oates, W. E. (1997). On the welfare gains from fiscal decentralization. Journal of Public Finance and Public Choice, 2-3: 83-92.

Oates, W. E. (1985). Searching for leviathan: An empirical study. The American Economic Review, 75(4): 748-757.

Oates, W.E. (1972). Fiscal Federalism. New York: Harcourt Brace Jovanovich.

Ostrom, V., Tiebout, C. M., \& Warren, R. (1961). The organization of government in metropolitan areas: a theoretical inquiry. The American Political Science Review, 55(4): $831-842$

Poole, R. (1983). Why not contract policing? Reason, 14:10.

Prud'homme, R. (1995). The dangers of decentralization. The World Bank Research Observer, 10(2): 201-220.

Samuelson, P. A. (1954). The pure theory of public expenditure. The Review of Economics and Statistics, 36(4): 387-389.

Saunders, P. (1985). Public expenditure and economic performance in OECD countries. Journal of Public Policy, 5(1): 1-21.

Schmandt, H. J., \& Stephens, G. R. (1960). Measuring municipal output. National Tax Journal, 13(4): 369-375.

Schneider, M. (1986). Fragmentation and the growth of local government. Public Choice, 48: 255-263.

Sjoquist, D. L. (1982). The effect of the number of local governments on central city expenditures. National Tax Journal, 35(1): 79-87. 
Sobel, R. (2004). Welfare economics and public finance. In J. G. Backhaus, \& R. E. Wagner, Handbook of public finance (pp. 19-51). New York: Springer.

Stansel, D. (2005). Local decentralization and local economic growth: A cross-sectional examination of US metropolitan areas. Journal of Urban Economics, 57: 55-72.

Tiebout, C. M. (1956). A pure theory of local expenditures. Journal of Political Economy, 65(4): $416-424$.

Zax, J. S. (1989). Is there a leviathan in your neighborhood? The American Economic Review, 79(3): 560-567. 